Article

\title{
Responses of Phytoplankton Communities in Selected Eutrophic Lakes to Variable Weather Conditions
}

\author{
Tomasz Lenard ${ }^{1, * \mathbb{D}}$, Wojciech Ejankowski ${ }^{2}$ and Małgorzata Poniewozik ${ }^{3}$ \\ 1 Department of Animal Physiology and Toxicology, Faculty of Biotechnology and Environment Sciences, \\ The John Paul II Catholic University of Lublin, Konstantynów 1i, PL-20-708 Lublin, Poland \\ 2 Regional Directorate for Environmental Protection in Lublin, Bazylianówka 46, PL-20-144 Lublin, Poland; \\ wojciech.ejankowski@gmail.com \\ 3 Department of Plant Physiology and Biotechnology, Faculty of Biotechnology and Environment Sciences, \\ The John Paul II Catholic University of Lublin, Konstantynów 1i, PL-20-708 Lublin, Poland; gonium@kul.pl \\ * Correspondence: tomasz.lenard@kul.pl; Tel.: +48-81-454-54-58
}

Received: 26 April 2019; Accepted: 4 June 2019; Published: 10 June 2019

\begin{abstract}
It is well-known that recent climatic changes have strongly affected aquatic ecosystems. In this study, we examined the complex factors determining the development of phytoplankton communities during the vegetative growth season in eutrophic lakes located in a temperate zone in eastern Poland. Our analysis enabled us to divide the data into two different periods: years with a cold winter and low total precipitation, and those with a mild winter and high total precipitation. The analysis showed that the soluble and total nitrogen content, concentration of chlorophyll $a$, total phytoplankton biomass, and biomasses of Cyanobacteria and Cryptophyceae were significantly higher in the vegetative growth season in the year after a mild winter, whereas the soluble and total phosphorus content and phytoplankton biodiversity were significantly lower in these years. Hence, climate warming indirectly led to the loss of biodiversity in the phytoplankton communities in the studied lakes of temperate zone. During this study, we also tested the effects of increases in air temperature and total precipitation on phytoplankton communities over short time periods (14 and 28 days). The results showed that the total phytoplankton biomass and the chlorophyll $a$ concentration were only positively correlated with the air temperature. All of the features described in this study showed how sensitive lake ecosystems are to climatic fluctuations.
\end{abstract}

Keywords: mild and cold winter; precipitation; temperature; physical and chemical parameters; phytoplankton community

\section{Introduction}

Many extreme weather events have happened in recent years. These are visible as regional climate disturbances, as well as changes on a global scale. Higher or lower air temperatures, longer or shorter winter periods, and droughts or intense precipitation events are all meteorological phenomena that are part of the ongoing climatic changes occurring in the world [1]. Such events and changes have happened naturally over the course of the history of the Earth, on a long timescale. However, recent climate changes have happened over an unusually short timescale due to the effects of humans on the environment. Thus, the concept of the Anthropocene has emerged to describe the time in which we are now living, and seems to be more and more appropriate [2,3].

All of the aforementioned changes in weather conditions are difficult to forecast because there are many factors that can affect the climate. Nonetheless, the future prognosis is for there to be successive increases in temperature and in the frequency of severe precipitation events in Europe [4,5], which will 
affect surface water temperatures of lakes, especially in spring and summer [6,7], as well as lead to a lack of ice, late ice formation, or early ice melting in lakes during winter [8-11]. The increases in precipitation events may enhance the hydration of catchment basins, influence the process of water runoff, and facilitate non-point delivery of biogenic compounds and organic carbon to lakes [12]. Consequently, the biotic elements in freshwater ecosystems will first respond through increases in the biomass of primary producers through the intensive development of phytoplankton and macrophytes, which leads to advanced eutrophication in lakes if it reaches very high amounts [12-14]. Hence, lakes are treated as valuable sentinels for detecting global changes, which in turn might have major direct and indirect effects on the biota of lakes [15].

The phytoplankton community in a lake is very sensitive to changes in abiotic parameters. This has been clearly shown in many previous studies concerning the global expansion of cyanobacterial blooms in lakes varying in trophic character, morphometry, hydrology, biogeography, and catchment properties [14,16-18]. Nonetheless, independently of a lake's type and its morphometric properties, as well as whether studies were performed in natural habitats or in laboratory experiments, increased temperature appears to play the most important role in the occurrence of cyanobacterial blooms [5,18-21]. This is because of the high environmental plasticity of cyanobacteria and the features that give them a competitive advantage over other phytoplankton, such as their ability to remain buoyant in the water column through the use of gas vesicles, form mucilaginous colonies for slower sinking, use a wide portion of the light spectrum for photosynthesis, form nitrogen-fixing heterocysts, use diverse reproductive strategies, multiply quickly in water, and have low susceptibility to grazing pressure [22,23] or produce a wide spectrum of toxins [24]. All of these properties can help these blue-green algae to hamper the development of other phytoplankton species, especially in the face of extreme precipitation events or changes in air temperature that can cause increased nutrient inputs to the surface waters or affect the thermal regime in the water column. Nonetheless, in lakes in temperate zones, other phytoplankton groups, such as diatoms or mixotrophic flagellate species such as cryptomonads and dinoflagellates, are able to grow well or even outcompete cyanobacteria during the colder months of the year (autumn, winter, or spring) [25,26]. Winter is a very important period, which can affect limnological processes not only during winter but also in the following growing season. However, hydrobiological field work during cold winters with thick ice cover, extreme low temperatures, and sometimes heavy snowfall can be very difficult. Similarly, field work during mild winters on lakes devoid of ice but during unpleasant weather conditions, e.g., strong wind and wave action, low temperatures, or heavy rainfall can create difficulties for researchers [27]. Nevertheless, winter limnology has been increasingly recognised in recent years [28-35]. The winter phytoplankton may be an inoculum for spring phytoplankton development and cause an early depletion of nutrients, and may also affect the food web in aquatic ecosystems during spring and summer [36,37]. Thus, the role of winter periods in shaping the phytoplankton community in a lake for the whole of the subsequent year has recently been widely discussed [38-41]. Simultaneously, there have also been some experimental studies which pointed out that selected chlorophytes and cyanobacteria can have similar optimum growth conditions. However, chlorophyte growth rates at their optimum temperature might even be significantly higher than those of cyanobacteria [42]. Thus, chlorophytes together with cyanobacteria can develop and grow well during hot summers. Therefore, the effect of climate warming, coupled with short-term extreme weather events (e.g., heavy rains, droughts, high temperatures, and the occurrence of a mild or cold winter) can lead to an increase in phytoplankton biomass, especially in closed lake ecosystems.

In this study, we analysed the effects of climatic variability (the type of winter and changes in temperature and total precipitation) on the physical and chemical parameters and phytoplankton communities in eutrophic lakes in a temperate zone. We hypothesised that the physical and chemical parameters of the water and the phytoplankton community during the growing season were linked to the following: (1) the occurrence of cold or mild winters preceding the vegetative growth season; (2) the changes in precipitation intensity during the year; and (3) the changes in the air temperature during the growing season. We also wanted to check whether these changes have led to divergent 
or similar responses in recent years among the studied lakes, which differed in their phytoplankton community compositions.

\section{Materials and Methods}

This study was carried out from 2010 to 2014 in four lakes-Głębokie, Gumienek, Czarne, and Maśluchowskie-all located near the village of Uścimów in the Western Polesie region, mid-eastern Poland. Western Polesie (latitude: $51^{\circ} 18^{\prime} 00^{\prime \prime}-51^{\circ} 57^{\prime} 00^{\prime \prime} \mathrm{N}$; longitude: $22^{\circ} 38^{\prime} 11^{\prime \prime}-24^{\circ} 09^{\prime} 00^{\prime \prime} \mathrm{E}$ ) is characterised by having a great number of lakes (more than 60), marshes, meadows, and swamps, and is part of a large geographical region referred to as Polesie and divided between three countries: Poland, Ukraine, and Belarus [43].

The studied lakes are all small, eutrophic, and have similar morphometric characteristics (Table 1). These bodies of water are situated in an agricultural landscape. Their catchment basins are relatively small (Table 1), and in the case of the Lakes Głebokie, Gumienek, and Maśluchowskie these consisted of arable land $(20.5 \%-73.5 \%)$, forests $(0.57 \%-23.9 \%)$, and meadows $(4.67 \%-7.57 \%)$. Only Lake Czarne is surrounded by an earth dyke (since the 1950s) and has a catchment basin with a largely limited area [44]. According to the Ohle's index (the quotient that results from the division of the total catchment area by the lake's surface area) [45], the studied lakes should be characterised as lakes with low susceptibility to the transport of biogenic matter (Ohle's index values from 2.5 to 8.6 ).

Table 1. Morphometric characteristics of the studied lakes in the West Polesie region, as described by Wilgat et al. [46].

\begin{tabular}{|c|c|c|c|c|c|c|c|c|}
\hline \multirow{2}{*}{ Lake } & \multirow{2}{*}{ Coordinates } & \multirow{2}{*}{$\begin{array}{l}\text { Area } \\
\text { (ha) }\end{array}$} & \multirow{2}{*}{$\begin{array}{l}\text { Length } \\
\text { (m) }\end{array}$} & \multirow{2}{*}{$\begin{array}{c}\text { Mean } \\
\text { Width (m) }\end{array}$} & \multicolumn{2}{|c|}{ Depth (m) } & \multirow{2}{*}{$\begin{array}{l}\text { Volume } \\
\left(10^{3} \mathrm{~m}^{3}\right)\end{array}$} & \multirow{2}{*}{$\begin{array}{l}\text { Catchment } \\
\text { Area (ha) }\end{array}$} \\
\hline & & & & & Max & Mean & & \\
\hline Głębokie & $\begin{array}{l}51^{\circ} 28^{\prime} 34^{\prime \prime} \mathrm{N} \\
22^{\circ} 55^{\prime} 23^{\prime \prime} \mathrm{E}\end{array}$ & 20.5 & 585 & 350 & 7.1 & 3.4 & 689 & 173.8 \\
\hline Gumienek & $\begin{array}{l}51^{\circ} 30^{\prime} 14^{\prime \prime} \mathrm{N} \\
22^{\circ} 56^{\prime} 20^{\prime \prime} \mathrm{E}\end{array}$ & 8.1 & 376 & 215 & 7.8 & 3.8 & 307 & 21.5 \\
\hline Czarne & $\begin{array}{l}51^{\circ} 29^{\prime} 08^{\prime \prime} \mathrm{N} \\
22^{\circ} 56^{\prime} 34^{\prime \prime} \mathrm{E}\end{array}$ & 24.8 & 596 & 416 & 10.3 & 3.7 & 915 & Earth dyke \\
\hline Maśluchowskie & $\begin{array}{l}51^{\circ} 28^{\prime} 03^{\prime \prime} \mathrm{N} \\
22^{\circ} 56^{\prime} 43^{\prime \prime} \mathrm{E}\end{array}$ & 26.7 & 861 & 310 & 9.4 & 4.6 & 1231 & 113.9 \\
\hline
\end{tabular}

Climatic data for total precipitation and air temperature from a meteorological station in the town of Włodawa located in the Polesie region were obtained from an online service (http://www.tutiempo.net). In this study, we included information about the total precipitation during each hydrological year, which in Poland begins on 1 November and continues until 31 October of the next year, as well as the total precipitation during the sampling months (from the beginning of May until the end of August). Additionally, we tested the effect of the mean air temperature during the period 14 days before sampling $\left(\mathrm{T}_{14}\right)$ and the total precipitation for 28 days before sampling on the physical, chemical and biological parameters of the lakes. The mean air temperature data were also used to determine the type of winter period that preceded each sampling year. We assumed that mid-March was an average time for winter ice cover breakup in Poland to occur [9]. The effects of a cold winter (CW) were studied in the years when the latest ice breakup date was observed to be later than mid-March, whereas the effects of a mild winter (MW) were studied when the latest ice breakup date occurred before this period. The physical, chemical and biological parameters were analysed to assess the differences between these two periods (CW and MW years).

Sampling was conducted every two weeks from May until the end of August in the years 2010-2014 (eight samples per year in each lake, 160 samples in total). Mixed water samples were collected from depths of $0.5,1.5$, and $3 \mathrm{~m}$ from the deepest part of each lake, which was marked in 2010 using a GPS receiver (Garmin 60Cx), using a Ruttner water sampler (2.0 L capacity). They were then analysed in the laboratory with spectrophotometric methods to determine the concentration of chlorophyll 
$a$ [47] and the total phosphorus (TP), total nitrogen (TN), inorganic phosphorus ( $\left(\mathrm{P}^{-} \mathrm{PO}_{4}\right)$, and nitrogen content $\left(\mathrm{DIN}=\mathrm{N}-\mathrm{NO}_{\mathrm{x}}+\mathrm{N}-\mathrm{NH}_{4}\right)$ in the water [48]. Additional physical and chemical parameters, including electrolytic conductivity (EC), relative acidity/alkalinity $(\mathrm{pH})$, and the depth of transparency determined with a Secchi disk visibility test (SD), were measured in situ. Additionally, the intensity of photosynthetically active radiation $\left(\mathrm{PAR}, I_{z}\right.$ ) was measured with a Li-Cor $192 \mathrm{SA}$ underwater quantum flat metre. The vertical light attenuation coefficient $\left(\mathrm{K}_{\mathrm{d}}\right)$ between adjacent depth intervals $(z$ and $z+$ $0.5 \mathrm{~m}$ ) was then calculated as:

$$
\mathrm{K}_{\mathrm{d}}=\left[\ln \left(I_{z}\right)-\ln \left(I_{z+0.5 \mathrm{~m}}\right)\right] 0.5 \mathrm{~m}^{-1},
$$

where $I_{z}$ is the PAR intensity value at a particular depth, $z$ [49].

The chemical and biological data were used to evaluate the trophic status of each lake using the trophic state indices TSI(CHL), TSI(SD), TSI(TP), and TSI(TN), which were calculated using the equations described by Carlson [50] and Kratzer and Brezonik [51].

The samples collected for phytoplankton analysis were fixed in Lugol's iodine solution and a formalin-glycerine mixture. The abundance of phytoplankton was determined according to standard methods [52], and the algal biovolume was calculated using the formula described by Hillebrand et al. [53]. Next, the phytoplankton biomass was calculated as a quotient of abundance and biovolume of individual species. The water samples were transferred to a settling chamber with a 5-50 mL capacity. After sedimentation, the algal abundance was evaluated using an inverted microscope (Zeiss Axiovert 135). In each chamber, small phytoplankton species were counted on the belts at $400 \times$ magnification (at least 200 individuals); larger forms (filamentous or coccal colonies) were counted on the entire bottom of the chamber at a magnification of 200x. A length of $100 \mu \mathrm{m}$ and a surface of $300 \mu^{2}$ were assumed for each individual filamentous and coccal colony, respectively. Additionally, samples for the taxonomic analysis of phytoplankton were collected using a plankton net (20 $\mu \mathrm{m}$ mesh size) and were left without fixation to observe live specimens under a light microscope (Nikon Eclipse 80i). For each of the two periods (CW and MW years), values of the Shannon-Wiener diversity index [54] and the Pielou's evenness index [55] were calculated based on the abundances of the different phytoplankton species in the community. For better ecological interpretation of the phytoplankton communities, the species were also divided into the appropriate morphological groups proposed by Reynolds [56], with some modifications and clarifications of the concept proposed by Padisak et al. [57].

The data were $\log _{10}$-transformed prior to analysis, or non-parametric tests were used if the data did not meet the assumptions of parametric tests after transformation. The normality of the residuals of the data was tested with the Lilleforst test, and the homogeneity of their variances was analysed with Levene's test. Detrended correspondence analysis (DCA) was employed using the MultiVariate Statistical Package (MVSP 3.11, Kovach Computing Services, Pentraeth, Isle of Anglesey, Wales, U.K.) to find the main factors or gradients that typified the ecological community data and could differentiate among the analysed lakes. Two-way analysis of variance (ANOVA) was then employed to test whether there was an interaction between the two independent variables, the type of winter (CW or MW) and the group to which each lake belonged (group A or B, based on the DCA results), and with the physical, chemical and biological parameters as the dependent variables. After the ANOVA, Tukey's honest significant difference post-hoc test (Tukey's HSD) was used to compare different treatment groups' means to one another. The relationships between the parameters describing water transparency (SD and $\mathrm{K}_{\mathrm{d}}$ ), climatic variability $\left(\mathrm{T}_{14}\right.$ and $\mathrm{PP}_{28}$ ), chemical parameters (soluble and total nitrogen and phosphorus content), and phytoplankton community parameters (the concentration of chlorophyll $a$ and the phytoplankton biomass) were evaluated with Spearman's rank correlation test. All of these calculations were performed according to Sokal and Rohlf [58] using Statistica 10. 


\section{Results}

A successive increase in mean air temperatures in the Western Polesie region across several years was noted (Figure 1a). This tendency was even greater during the study period (2010-2014; Figure 1b). Based on the mean air temperature data, we determined that there were two main winter periods that affected the physical and chemical, as well as the biological, parameters of the studied lakes; these were years that followed a cold winter $(\mathrm{CW})$, when the latest ice breakup date was observed to be after mid-March, and those that followed a mild winter (MW), when the latest ice breakup date was observed to be before this period. According to this, a CW was noted in the years 2010, 2012, and 2013, and a MW occurred in the years 2011 and 2014 (Figure 1b). The amplitude of the ice duration during the five years of this study was high. The earliest ice breakup was observed in the second 10-day period of February after the winter of 2014 (a MW), and the latest ice breakup was observed in the second 10-day period of April after the winter of 2013 (a CW). Hence, the difference between the earliest and the latest ice breakup date observed was around 60 days.

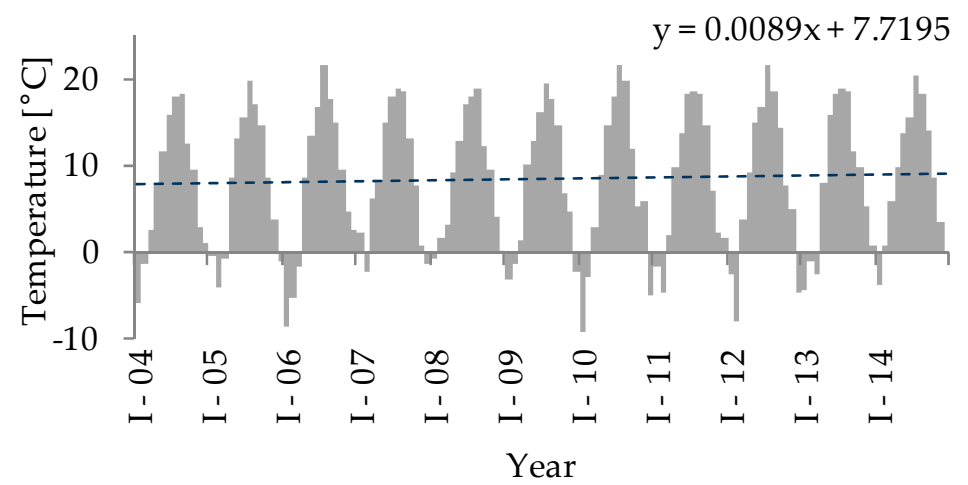

(a)

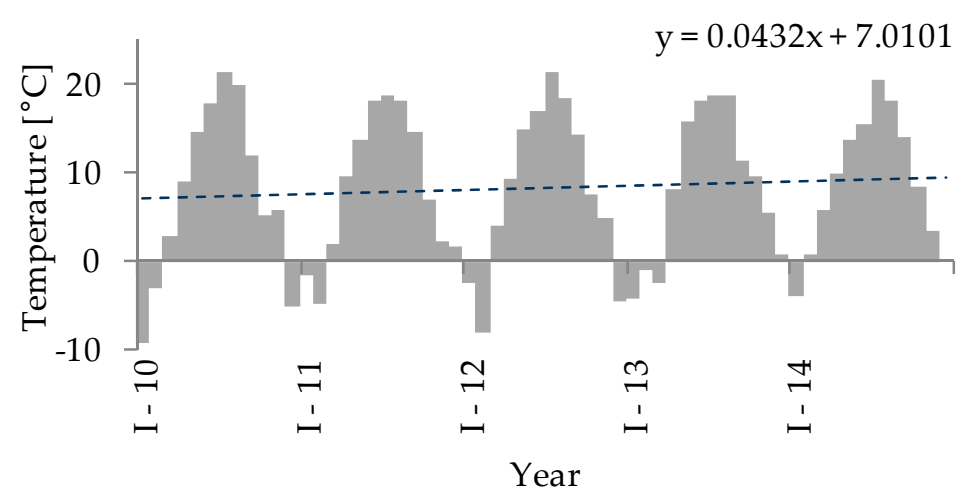

(b)

Figure 1. Monthly mean air temperature for two periods: (a) 2004-2014; (b) 2010-2014. The dashed line represents the trend line of changes in air temperature over time.

The total precipitation also showed an increasing tendency over the last decade (Figure 2a), as well as during the studied period (Figure $2 b$ ), and the amount of total precipitation corresponded to the type of winter that occurred. During hydrological years with a MW, the mean total precipitation was $717.4 \mathrm{~mm}$, whereas in hydrological years with a CW, the mean total precipitation was much lower at $579.8 \mathrm{~mm}$. Similarly, the mean total precipitation during the studied months (from the beginning of May until the end of August) differed greatly between the periods after a MW and after a CW, with 456.4 and $292.9 \mathrm{~mm}$, respectively (Figure $2 \mathrm{~b}$ ). This large difference resulted from some extreme precipitation events that took place during the vegetative growth season in the hydrological years after a MW, specifically in July 2011 and May 2014 (Figure 2b). 


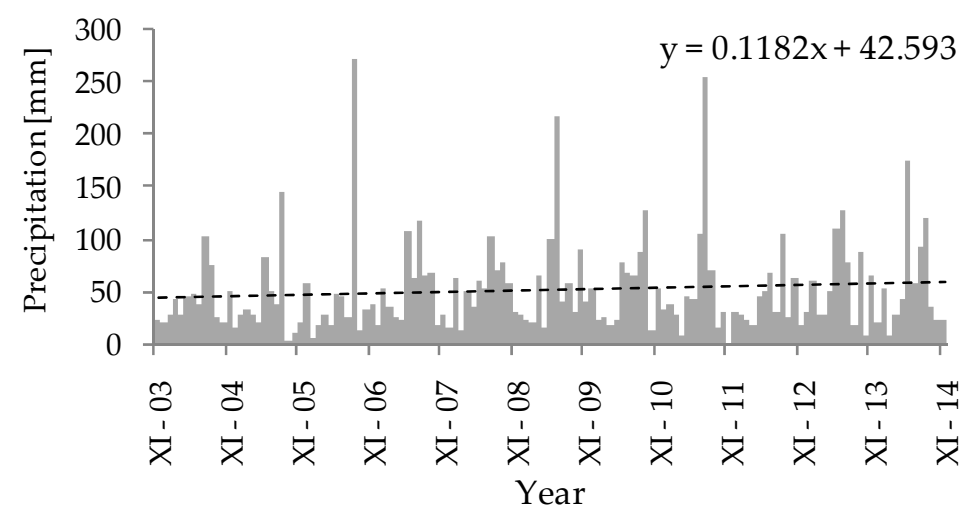

(a)

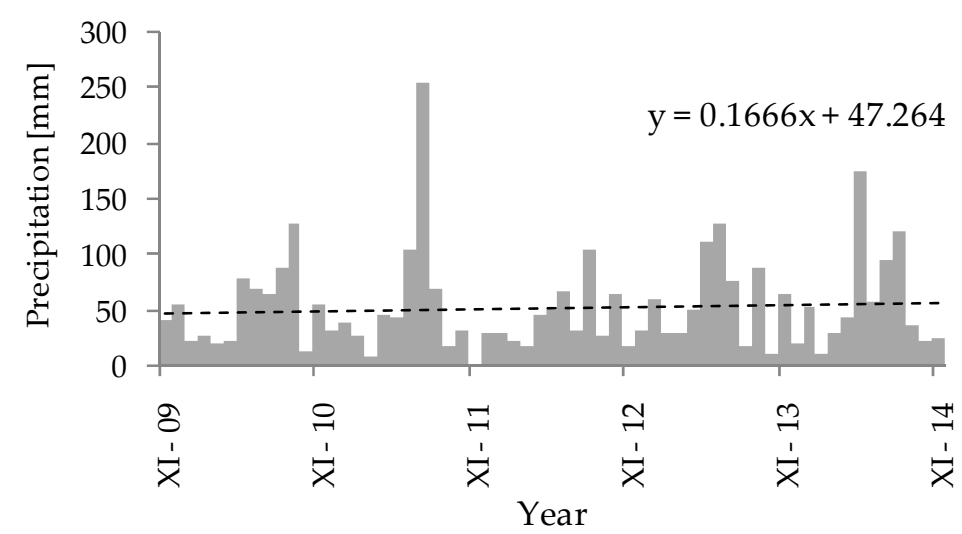

(b)

Figure 2. Monthly precipitation totals for two periods: (a) 2004-2014; (b) 2010-2014. The dashed line represents the trend line of changes in precipitation over time.

We wanted to check if there were any relationships between the changes in meteorological factors, i.e., the presence of extreme precipitation or temperature events, measured over short periods of time and the reaction of the aquatic environment. Hence, the effects of temperature and precipitation on the biological and chemical parameters of the lakes were also studied over short intervals of 14 and 28 days before sampling, respectively. The chlorophyll $a$ concentration and the phytoplankton biomass increased with the mean air temperature $\left(\mathrm{T}_{14}\right.$ days $)$, whereas no effect of total precipitation $\left(\mathrm{PP}_{28}\right.$ days $)$ was found (Figure 3 ). The $\mathrm{T}_{14}$ days was positively correlated with the chlorophyll $a$, concentration, total phytoplankton biomass, and biomasses of Cyanobacteria and Chlorophyta, with Spearman's correlation coefficients $(\varrho)$ of $0.37,0.38,0.34$, and 0.28 , respectively $(\mathrm{p}<0.001, \mathrm{n}=159)$. The consequence of the high amount of phytoplankton biomass at high temperatures was an increase in water turbidity, as was shown by the negative correlation of $\mathrm{T}_{14}$ days with the SD values found (Spearman's $\varrho=-0.20$, $\mathrm{p}<0.01, \mathrm{n}=159$ ), and the positive correlation of $\mathrm{T}_{14 \text { days }}$ with the $\mathrm{K}_{\mathrm{d}}$ values (Spearman's $\varrho=0.17$, $\mathrm{p}<0.01, \mathrm{n}=159)$. The total precipitation $\left(\mathrm{PP}_{28}\right.$ days $)$ had indirect effects on the phytoplankton biomass and chlorophyll $a$ concentration through inducing changes in water chemistry. The $\mathrm{PP}_{28}$ days was positively correlated with the DIN (Spearman's $\varrho=0.30, \mathrm{p}<0.001, \mathrm{n}=159$ ) and negatively correlated with the $\mathrm{P}_{-} \mathrm{PO}_{4}$ (Spearman's $\varrho=-0.19, \mathrm{p}<0.05, \mathrm{n}=159$ ), which was positively correlated with chlorophyll $a$ concentration and phytoplankton biomass (Spearman's $\varrho=0.24$ and 0.22 , respectively, $\mathrm{p}<0.001, \mathrm{n}=159)$. 

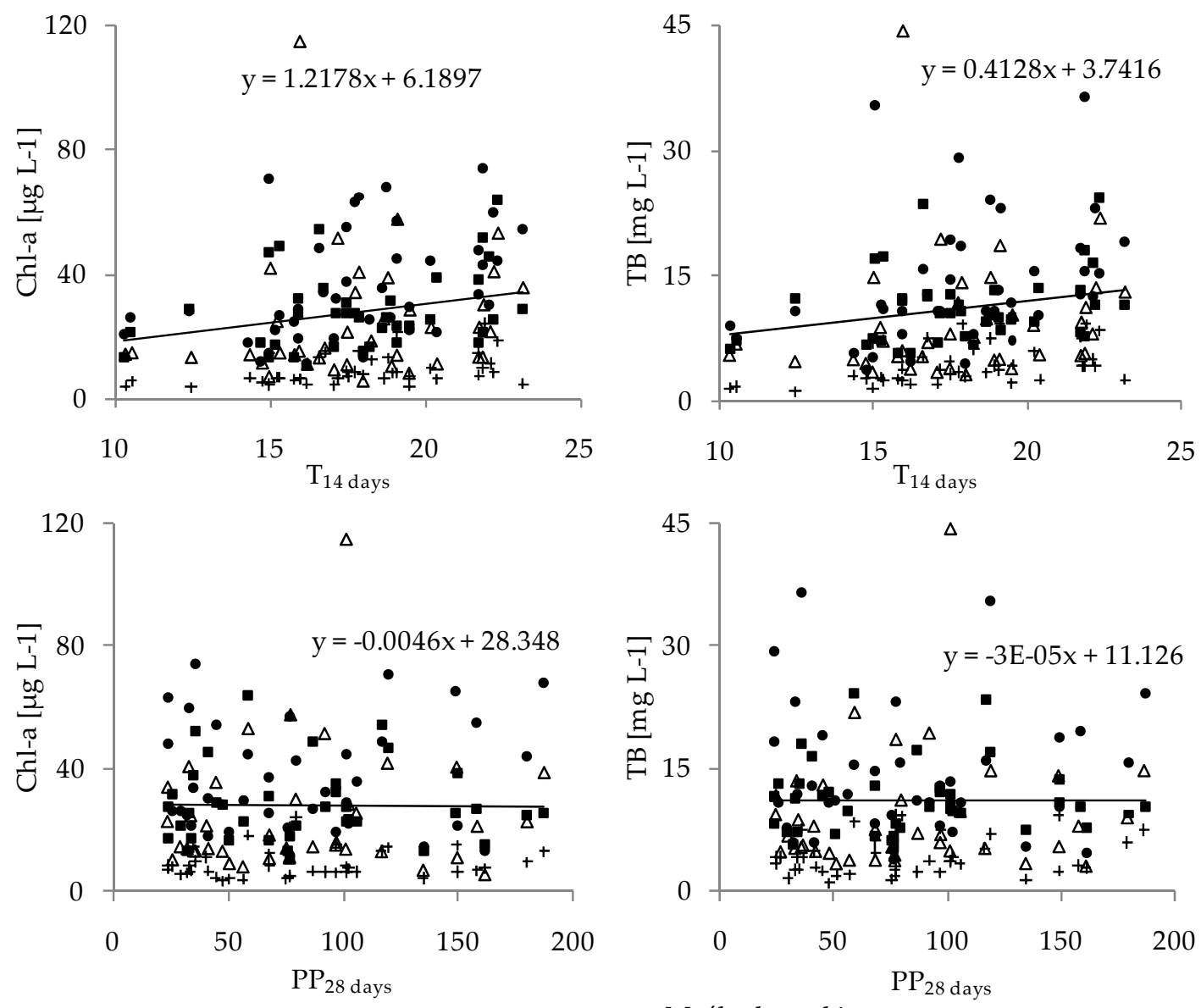

- Gumienek • Głębokie + Czarne

$\Delta$ Maśluchowskie

Figure 3. Relationship between the concentration of chlorophyll $a(\mathrm{Chl}-a)$ and the phytoplankton biomass $(\mathrm{TB})$ and the mean air temperature $\left(\mathrm{T}_{14}\right.$ days; upper panel) and total precipitation $\left(\mathrm{PP}_{28}\right.$ days; lower panel) in the studied lakes during the investigation period (2010-2014).

The physical and chemical parameters measured had strong influences on the development of the phytoplankton communities and the concentration of chlorophyll $a$. Hence, large discrepancies were noted due to biological parameters that resulted from differences among the studied lakes. Generally, high concentrations of chlorophyll $a$ and phytoplankton biomasses were observed in Lake Głębokie, whereas very low values of these were found in Lake Czarne, although an extremely high concentration of chlorophyll $a\left(114.5 \mu \mathrm{g} \mathrm{L}^{-1}\right)$ and phytoplankton biomass $\left(44.3 \mathrm{mg} \mathrm{L}^{-1}\right)$ was seen in Lake Maśluchowskie in July 2011 (Figure 4). The phytoplankton community was dominated by three groups: Cyanobacteria (mainly from codon H1-dinitrogen-fixing nostocaleans, or S1—cyanobacteria of turbid mixed layers), Cryptophyceae (codon Y-cryptomonads of small enriched lakes), and Chlorophyceae (mainly from codon F-chlorophytes of clear epilimnion, $\mathrm{P}$-chlorophytes of eutrophic epilimnion, or J-chlorophytes of shallow enriched lakes) (Figures 4 and 5). The highest biomasses of Cyanobacteria and Cryptophyceae were found in Lakes Głębokie and Gumienek, whereas the biomasses of both these groups were lower in Lakes Czarne and Maśluchowskie (Figure 4a,b). However, an extremely high biomass of Cyanobacteria ( $28 \mathrm{mg} \mathrm{L}^{-1}$ ) was seen in July 2011 in Lake Maśluchowskie (Figure 4d). During this study, the Cyanobacteria group was dominated by filamentous species, including Limnothrix planctonica (Woloszynska) Meffert and Planktolyngbya limnetica (Lemmermann) Komárková-Legnerová and Cronberg in Lake Głębokie, and Limnothrix redekei (Goor) Meffert, Limnothrix planctonica, and Planktothrix agardhii (Gomont) Anagnostidis et Komárek in Lake Gumienek, all belonging to functional group S1 (Figure 4a,b). In Lakes Czarne and Maśluchowskie, the most abundant blue-green alga was Aphanizomenon gracile (Lemmermann) Lemmermann, belonging to codon H1. Among the 
Cryptophyceae group, Cryptomonas marssonii Skuja and Cryptomonas curvata Ehrenberg (belonging to codon Y) were present in all lakes (Figure 4). Only one more group, Chlorophyta, with the dominant species being Coenococcus planctonicus Korshikov (codon F), made up large portions of the phytoplankton biomass in all lakes throughout this study. There were also other green algae present at higher biomasses representing codon J from the genera Pediastrum, Stauridium, Coelastrum, Scenedesmus, and Desmodesmus, or representing codon P from the genera Staurastrum and Clostridium; however, none of the species in a particular genus dominated in the communities (Figure 4). The proportion of the community biomass composed of other phytoplankton species found in the analysed samples belonging to the groups Euglenophyta, Dinophyceae, Chrysophyceae, and Bacillariophyceae (Figure 5), and representing codons $\mathrm{C}, \mathrm{D}, \mathrm{E}, \mathrm{G}, \mathrm{K}, \mathrm{L}_{\mathrm{M}}, \mathrm{MP}, \mathrm{N}, \mathrm{W} 1, \mathrm{~W} 2, \mathrm{X} 1, \mathrm{X} 2$, and $\mathrm{X} 3$, was negligible.

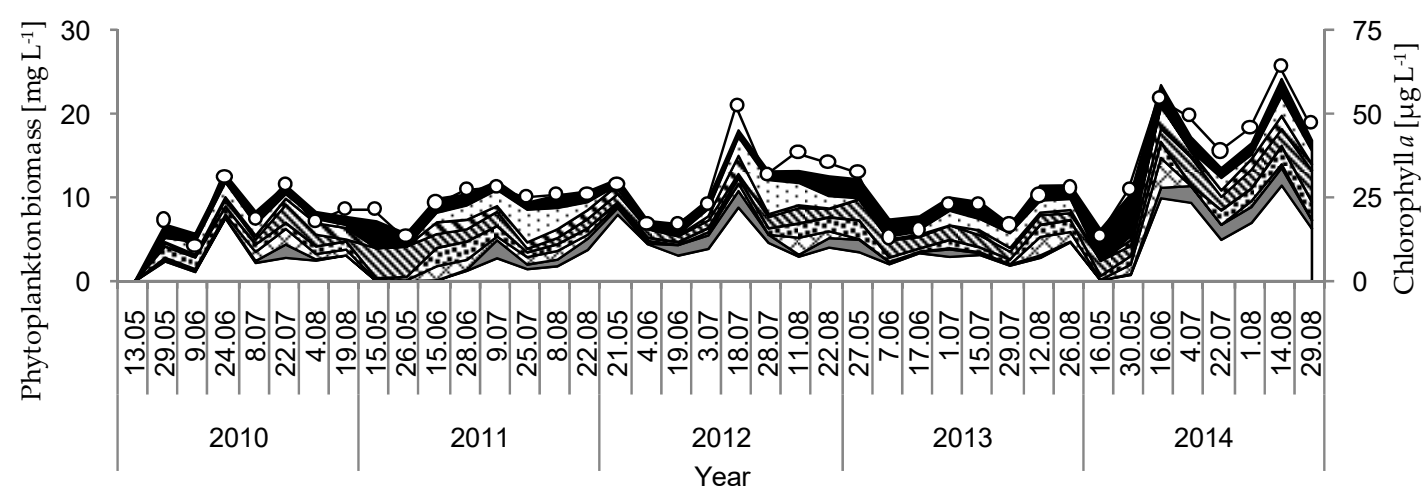

(a)

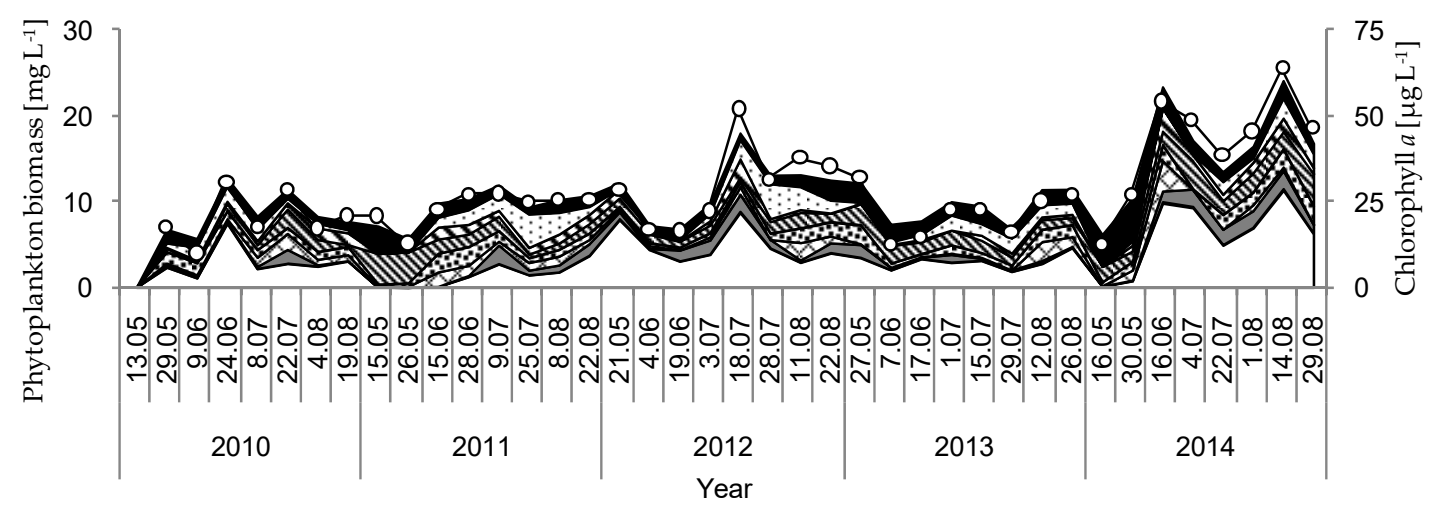

(b)

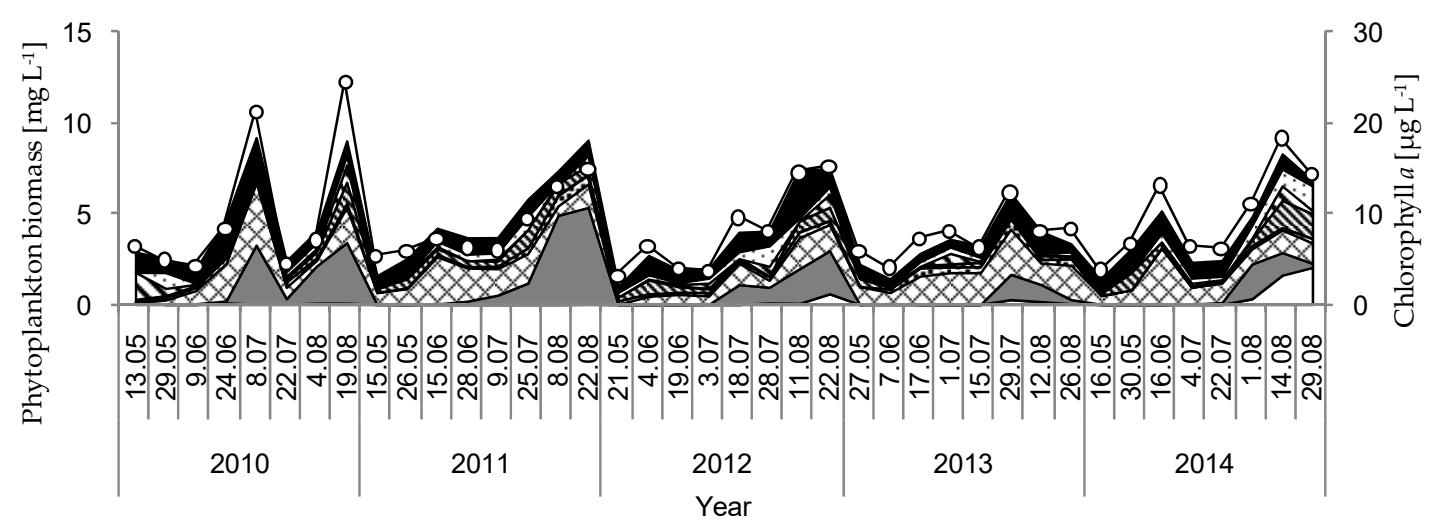

(c)

Figure 4. Cont. 


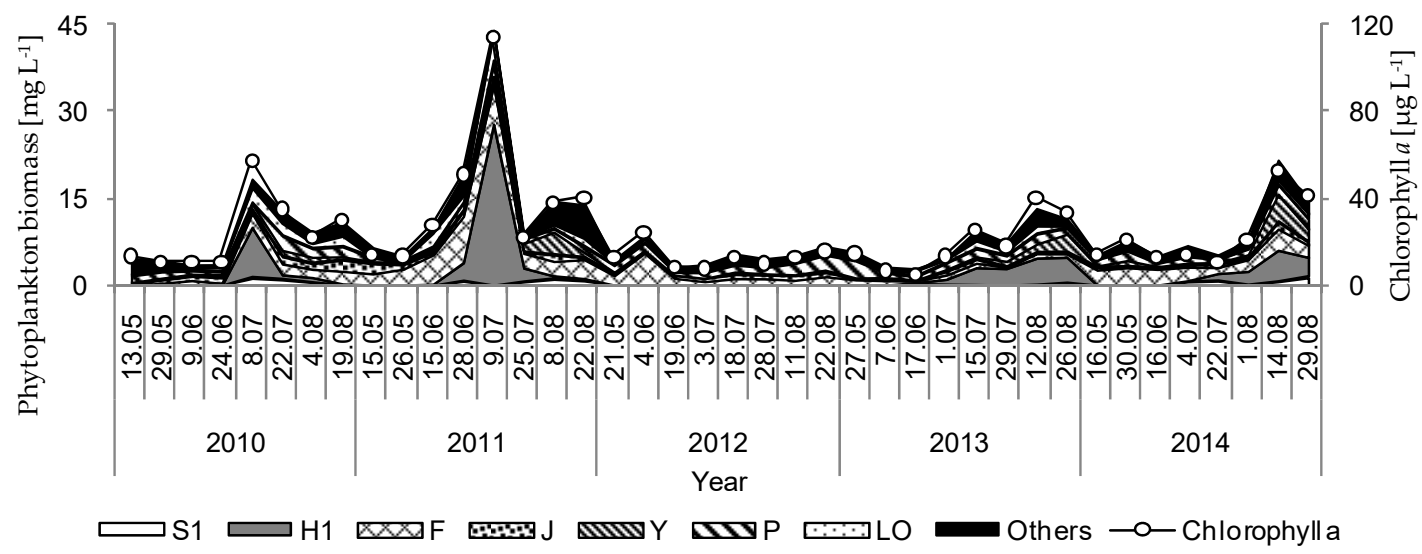

(d)

Figure 4. Temporal variation in the biomass of different phytoplankton functional groups and the concentration of chlorophyll $a$ during the investigation period (2010-2014) in the studied lakes: (a) GŁębokie; (b) Gumienek; (c) Czarne; (d) Maśluchowskie. Explanations: S1—cyanobacteria of turbid mixed layers; H1—dinitrogen-fixing nostocaleans; F-chlorophytes of clear epilimnion; J—chlorophytes of shallow enriched lakes; Y-cryptomonads of small enriched lakes; P-chlorophytes of eutrophic epilimnion; Lo-various species typical of summer epilimnion in mesotrophic lakes.

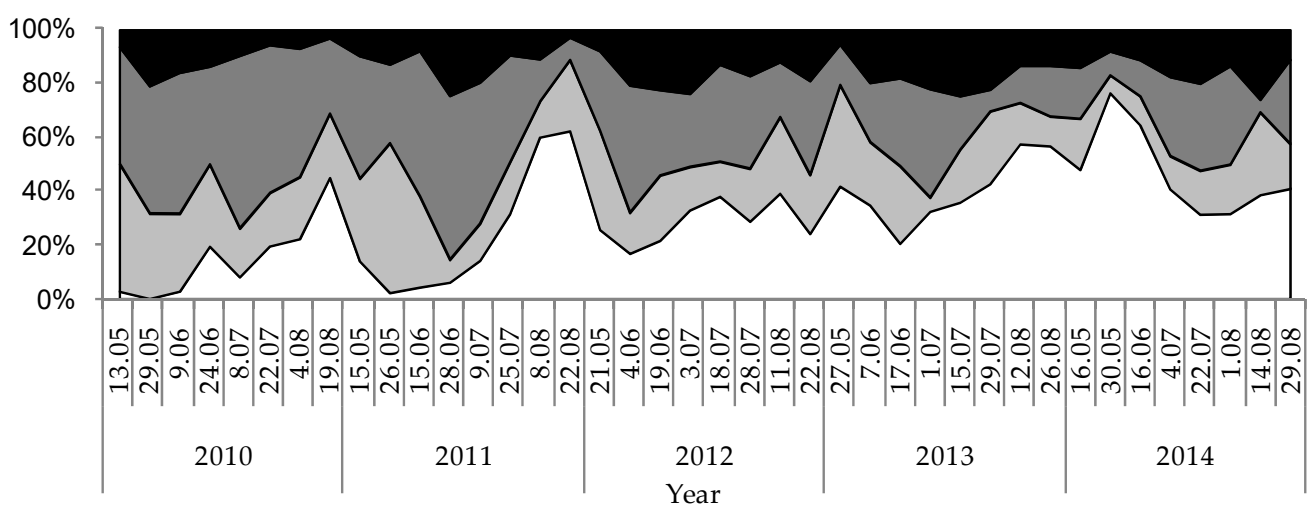

(a)

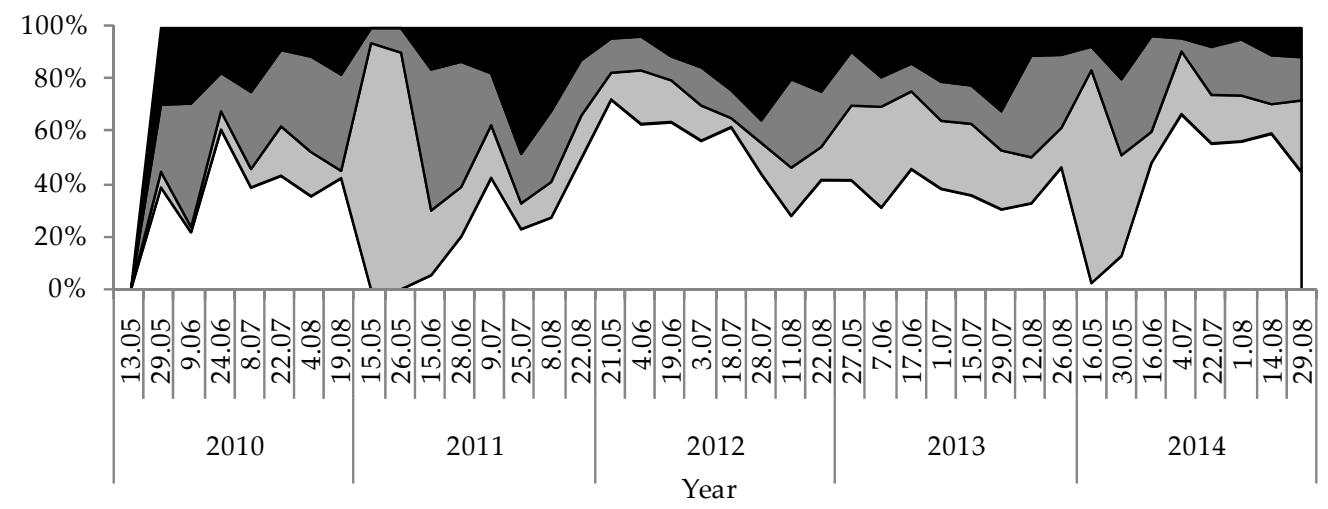

(b)

Figure 5. Cont. 


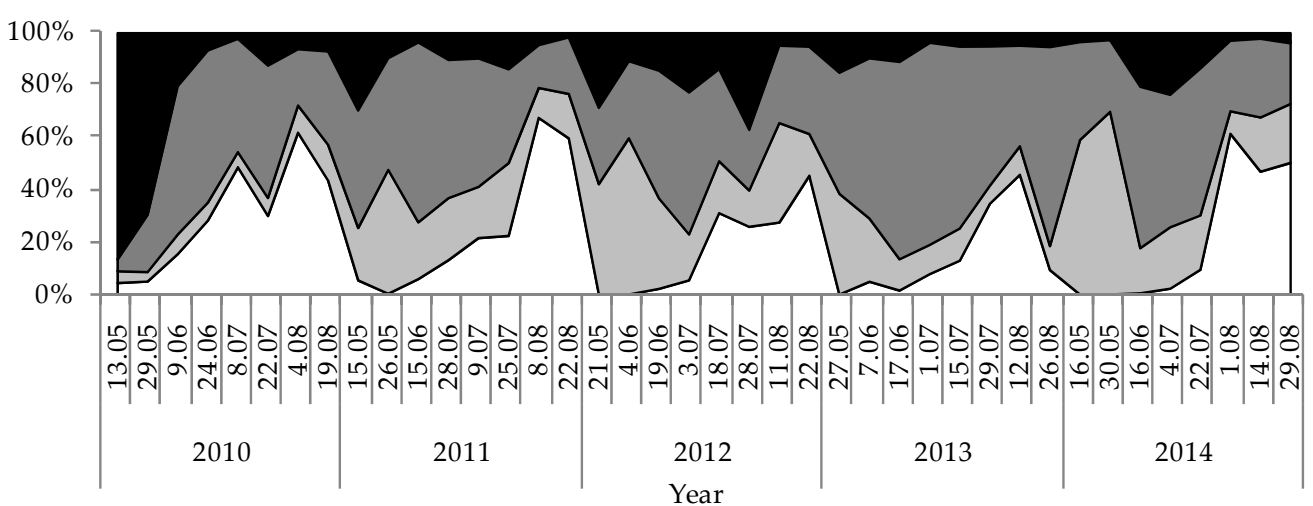

(c)

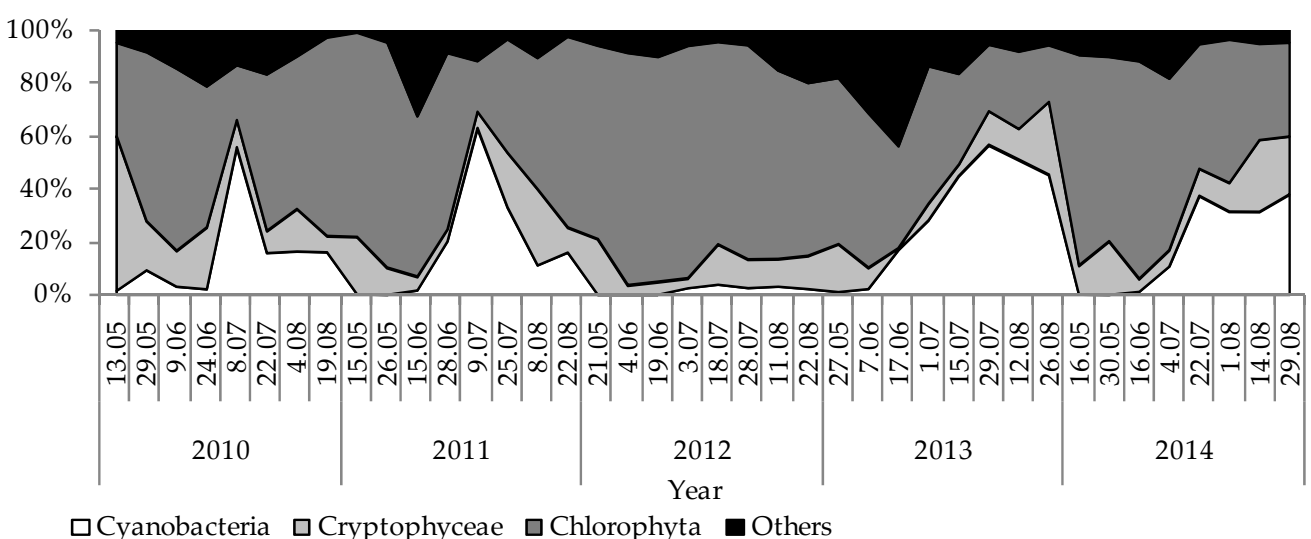

(d)

Figure 5. Temporal variation of percentage shares of phytoplankton groups based on biomass during the investigation period (2010-2014) in the studied lakes: (a) GŁębokie; (b) Gumienek; (c) Czarne; (d) Maśluchowskie.

Detrended correspondence analysis (DCA) was employed to check whether some factors or gradients existed that could be used to differentiate the studied lakes. The results of the DCA clearly showed that the lakes could be divided into two groups: group A, composed of the samples from the Lakes Głebokie and Gumienek, and group B, composed of the samples from Lakes Czarne and Maśluchowskie (Figure 6). The main factor that differentiated the groups was the phytoplankton functional groups present in them. In both groups, large portions of the phytoplankton biomass were made up of Cyanobacteria. However, in group A, the cyanobacterial species present belonged to codon $\mathrm{S} 1$, while those in group B belonged to codon H1. Additionally, the green algae from codon F were often present in the group B lakes, but only sporadically in group A. This analysis also found that the values of the phytoplankton biomass were important, as these were generally much higher in the lakes from group A than in those from group B (Figure 4, Table 2). 


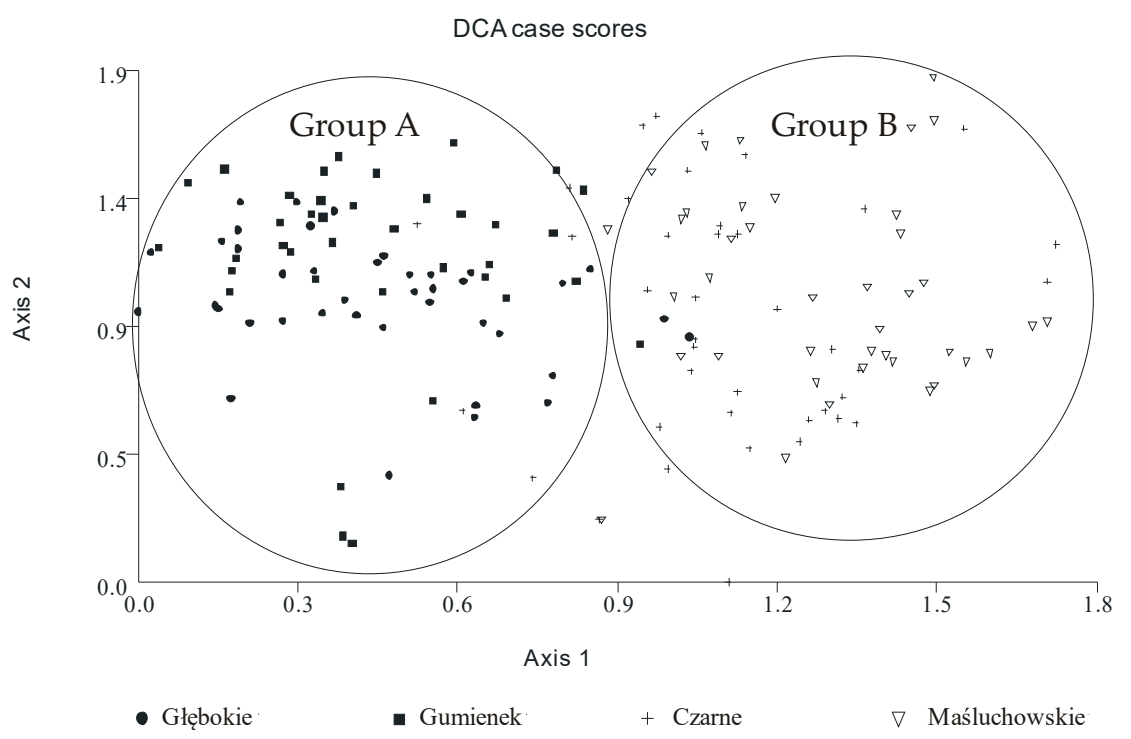

Figure 6. Detrended correspondence analysis (DCA) of the phytoplankton communities in the studied lakes during the investigation period (2010-2014).

On the basis of the results of the DCA, we decided to test whether the interaction between the type of winter (CW or MW years) and the lake group (group A and B lakes) had a significant effect on the physical, chemical and biological parameters of the lakes' water and phytoplankton communities. Hence, we tested the effect of this interaction using two-way ANOVA. The results of these analyses showed that variations in most of the physical and chemical parameters were independent of the group to which the lakes belonged but were highly dependent on the type of winter that preceded the sampling year (Table 2). This is shown in Table 2, with there being small differences between groups A and B after particular winter types, and large differences within each group of lakes between different winter types (CW vs. MW years). After a MW, the content of total and soluble nitrogen (TN, DIN, and the DIN/TN ratio) and the TSI(TN) were higher, and the content of total and soluble phosphorus (TP and $\mathrm{P}-\mathrm{PO}_{4}$ ) and the TSI(TP) were lower, than after a CW. Hence, the TN:TP ratio was also higher after a MW (Table 2). This relationship was clearly shown by the deviation between the trends in the TSI(TN) and TSI(TP) values (Figure 7). Nonetheless, no differences in the electrolytic conductivity, $\mathrm{pH}$, and water temperature were found between the compared periods (Table 2). Among the biological factors, the results of two-way ANOVA showed that there was a significant effect of the interaction between the group of lakes and the type of winter. However, despite the fact that groups A and B considerably differed in their values of particular biological factors, the general effect of the type of winter still remained significant. Hence, the concentration of chlorophyll a, TSI(CHL), total phytoplankton biomass, and biomasses of Cyanobacteria and Cryptophyceae varied with the type of winter, and were all significantly higher after a MW than a CW. The biomasses of other phytoplankton groups, including Chlorophyta (mainly represented by codons F, J, and P), which made up large portions of the phytoplankton biomass throughout this study (Figure 4), did not show significant differences between the two winter periods. However, the number of species, phytoplankton diversity (Shannon-Wiener index), and the evenness (Pielou's index) were significantly lower after a MW than after a CW. In accordance with the trends in the concentrations of chlorophyll $a$ and phytoplankton biomass, the values of the attenuation coefficient $\left(K_{d}\right)$ were higher and the values of water transparency (SD), expressed also in the values of TSI(SD), were lower after a MW than after a $\mathrm{CW}$ (Table 2). Moreover, the $\mathrm{K}_{\mathrm{d}}$ values were positively correlated with the concentration of chlorophyll $a$ and the phytoplankton biomass (Spearman's $\varrho=0.82$ and 0.80 , respectively, $\mathrm{p}<0.001, \mathrm{n}=159$ ). Conversely, the values of SD were negatively correlated with the aforementioned biological parameters (Spearman's $\varrho=-0.88$ and -0.87 , respectively, $\mathrm{p}<0.001, \mathrm{n}=159$ ). 
Table 2. Mean values ( \pm standard deviations) of the biological, physical and chemical parameters compared between the growing seasons after a cold (CW) and mild winter (MW) in the best-fitting two-way ANOVA model. Selected effects related to the types of winter are presented below. Explanations: A-mean values for Lakes Głębokie and Gumienek; B-mean values for Lakes Czarne and Maśluchowskie.

\begin{tabular}{|c|c|c|c|c|c|c|c|c|}
\hline \multirow{3}{*}{ Parameter } & \multicolumn{3}{|c|}{$\mathrm{CW}$} & \multicolumn{3}{|c|}{ MW } & \multirow{3}{*}{$d f$} & \multirow{3}{*}{ F-test } \\
\hline & \multicolumn{3}{|c|}{ Group of Lakes } & \multicolumn{3}{|c|}{ Group of Lakes } & & \\
\hline & A & B & $\begin{array}{c}\text { All } \\
\text { Lakes }\end{array}$ & A & B & $\begin{array}{c}\text { All } \\
\text { Lakes }\end{array}$ & & \\
\hline Chl- $a\left(\mu \mathrm{g} \mathrm{L}^{-1}\right)$ & $\begin{array}{c}29.39 \\
( \pm 15.0)\end{array}$ & $\begin{array}{c}13.79 \\
( \pm 10.9)\end{array}$ & $\begin{array}{c}21.51 \\
( \pm 15.2)\end{array}$ & $\begin{array}{c}36.05 \\
( \pm 16.3)\end{array}$ & $\begin{array}{c}20.62 \\
( \pm 21.7)\end{array}$ & $\begin{array}{c}28.34 \\
( \pm 20.6)\end{array}$ & 1 & $6.95^{* *}$ \\
\hline $\begin{array}{l}\text { Total Biomass } \\
\qquad\left(\mathrm{mg} \mathrm{L}^{-1}\right)\end{array}$ & $\begin{array}{l}11.79 \\
( \pm 6.3)\end{array}$ & $\begin{array}{c}5.55 \\
( \pm 3.6)\end{array}$ & $\begin{array}{c}8.64 \\
( \pm 6.0)\end{array}$ & $\begin{array}{l}13.51 \\
( \pm 6.5)\end{array}$ & $\begin{array}{c}8.49 \\
( \pm 8.2)\end{array}$ & $\begin{array}{l}11.01 \\
( \pm 7.7)\end{array}$ & 1 & $6.47^{*}$ \\
\hline $\begin{array}{c}\text { Cyanobacteria } \\
\left(\mathrm{mg} \mathrm{L}^{-1}\right)\end{array}$ & $\begin{array}{c}4.43 \\
( \pm 3.4)\end{array}$ & $\begin{array}{l}1.39 \\
( \pm 2.1)\end{array}$ & $\begin{array}{c}2.89 \\
( \pm 3.2)\end{array}$ & $\begin{array}{c}5.54 \\
( \pm 5.0)\end{array}$ & $\begin{array}{l}2.52 \\
( \pm 5.1)\end{array}$ & $\begin{array}{c}4.03 \\
( \pm 5.2)\end{array}$ & 1 & $4.47^{*}$ \\
\hline $\begin{array}{c}\text { Cryptophyceae } \\
\left(\mathrm{mg} \mathrm{L}^{-1}\right)\end{array}$ & $\begin{array}{c}2.18 \\
( \pm 1.2)\end{array}$ & $\begin{array}{c}0.78 \\
( \pm 0.7)\end{array}$ & $\begin{array}{c}1.47 \\
( \pm 1.2)\end{array}$ & $\begin{array}{c}2.92 \\
( \pm 1.5)\end{array}$ & $\begin{array}{l}1.35 \\
( \pm 1.2)\end{array}$ & $\begin{array}{c}2.14 \\
( \pm 1.6)\end{array}$ & 1 & $14.65^{* * *}$ \\
\hline $\begin{array}{l}\text { Euglenophyta } \\
\left(\mathrm{mg} \mathrm{L}^{-1}\right)\end{array}$ & $\begin{array}{c}0.32 \\
( \pm 0.3)\end{array}$ & $\begin{array}{c}0.03 \\
( \pm 0.0)\end{array}$ & $\begin{array}{c}0.17 \\
( \pm 0.2)\end{array}$ & $\begin{array}{c}0.29 \\
( \pm 0.3)\end{array}$ & $\begin{array}{c}0.05 \\
( \pm 0.0)\end{array}$ & $\begin{array}{c}0.17 \\
( \pm 0.2)\end{array}$ & 1 & 0.02 \\
\hline $\begin{array}{l}\text { Dinophyceae } \\
\left(\mathrm{mg} \mathrm{L}^{-1}\right)\end{array}$ & $\begin{array}{c}0.87 \\
( \pm 0.8)\end{array}$ & $\begin{array}{c}0.31 \\
( \pm 0.5)\end{array}$ & $\begin{array}{c}0.59 \\
( \pm 0.7)\end{array}$ & $\begin{array}{c}0.79 \\
( \pm 0.9)\end{array}$ & $\begin{array}{c}0.44 \\
( \pm 0.9)\end{array}$ & $\begin{array}{c}0.61 \\
( \pm 0.9)\end{array}$ & 1 & 0.15 \\
\hline $\begin{array}{l}\text { Chrysophyceae } \\
\left(\mathrm{mg} \mathrm{L}^{-1}\right)\end{array}$ & $\begin{array}{c}0.11 \\
( \pm 0.2)\end{array}$ & $\begin{array}{c}0.06 \\
( \pm 0.1)\end{array}$ & $\begin{array}{c}0.09 \\
( \pm 0.2)\end{array}$ & $\begin{array}{c}0.14 \\
( \pm 0.3)\end{array}$ & $\begin{array}{c}0.05 \\
( \pm 0.0)\end{array}$ & $\begin{array}{c}0.09 \\
( \pm 0.2)\end{array}$ & 1 & 0.02 \\
\hline $\begin{array}{l}\text { Bacillariophyceae } \\
\left(\mathrm{mg} \mathrm{L}^{-1}\right)\end{array}$ & $\begin{array}{c}0.51 \\
( \pm 0.6)\end{array}$ & $\begin{array}{c}0.26 \\
( \pm 0.4)\end{array}$ & $\begin{array}{c}0.39 \\
( \pm 0.5)\end{array}$ & $\begin{array}{c}0.47 \\
( \pm 0.6)\end{array}$ & $\begin{array}{c}0.19 \\
( \pm 0.3)\end{array}$ & $\begin{array}{c}0.33 \\
( \pm 0.5)\end{array}$ & 1 & 0.96 \\
\hline $\begin{array}{l}\text { Chlorophyta } \\
\left(\mathrm{mg} \mathrm{L}^{-1}\right)\end{array}$ & $\begin{array}{c}3.38 \\
( \pm 3.0)\end{array}$ & $\begin{array}{c}2.71 \\
( \pm 1.8)\end{array}$ & $\begin{array}{c}3.05 \\
( \pm 2.5)\end{array}$ & $\begin{array}{c}3.38 \\
( \pm 2.4)\end{array}$ & $\begin{array}{c}3.88 \\
( \pm 2.9)\end{array}$ & $\begin{array}{l}3.63 \\
( \pm 2.7)\end{array}$ & 1 & 2.03 \\
\hline Species richness & $\begin{array}{c}41.6 \\
( \pm 8.1)\end{array}$ & $\begin{array}{c}32.0 \\
( \pm 7.7)\end{array}$ & $\begin{array}{c}36.7 \\
( \pm 9.2)\end{array}$ & $\begin{array}{c}34.4 \\
( \pm 9.3)\end{array}$ & $\begin{array}{c}26.4 \\
( \pm 8.3)\end{array}$ & $\begin{array}{c}30.4 \\
( \pm 9.7)\end{array}$ & 1 & $22.45^{* * *}$ \\
\hline $\begin{array}{l}\text { Shannon-Wiener } \\
\text { diversity index }\left(\mathrm{H}^{\prime}\right)\end{array}$ & $\begin{array}{c}2.05 \\
( \pm 0.6)\end{array}$ & $\begin{array}{c}2.15 \\
( \pm 0.6)\end{array}$ & $\begin{array}{c}2.10 \\
( \pm 0.6)\end{array}$ & $\begin{array}{c}1.92 \\
( \pm 0.6)\end{array}$ & $\begin{array}{c}1.74 \\
( \pm 0.6)\end{array}$ & $\begin{array}{l}1.83 \\
( \pm 0.6)\end{array}$ & 1 & $7.39 * *$ \\
\hline Pielou's evenness (J) & $\begin{array}{c}0.55 \\
( \pm 0.1)\end{array}$ & $\begin{array}{c}0.61 \\
( \pm 0.1)\end{array}$ & $\begin{array}{c}0.59 \\
( \pm 0.1)\end{array}$ & $\begin{array}{c}0.54 \\
( \pm 0.1)\end{array}$ & $\begin{array}{c}0.53 \\
( \pm 0.1)\end{array}$ & $\begin{array}{c}0.53 \\
( \pm 0.1)\end{array}$ & 1 & $3.94 *$ \\
\hline TSI (TN) & $\begin{array}{c}63.3 \\
( \pm 7.7)\end{array}$ & $\begin{array}{c}62.3 \\
( \pm 7.7)\end{array}$ & $\begin{array}{c}62.8 \\
( \pm 7.7)\end{array}$ & $\begin{array}{c}73.9 \\
( \pm 5.9)\end{array}$ & $\begin{array}{c}71.1 \\
( \pm 6.9)\end{array}$ & $\begin{array}{c}72.5 \\
( \pm 6.5)\end{array}$ & 1 & $68.01^{* * *}$ \\
\hline TSI (TP) & $\begin{array}{c}72.7 \\
( \pm 11.6)\end{array}$ & $\begin{array}{c}69.3 \\
( \pm 13.6)\end{array}$ & $\begin{array}{c}71 \\
( \pm 12.7)\end{array}$ & $\begin{array}{c}59.7 \\
( \pm 4.9)\end{array}$ & $\begin{array}{c}54.1 \\
( \pm 7.2)\end{array}$ & $\begin{array}{c}56.9 \\
( \pm 6.7)\end{array}$ & 1 & $68.59^{* * *}$ \\
\hline TSI (CHL) & $\begin{array}{c}62.6 \\
( \pm 4.8)\end{array}$ & $\begin{array}{c}54.0 \\
( \pm 6.6)\end{array}$ & $\begin{array}{c}58.3 \\
( \pm 7.3)\end{array}$ & $\begin{array}{c}64.8 \\
( \pm 4.4)\end{array}$ & $\begin{array}{c}56.9 \\
( \pm 7.7)\end{array}$ & $\begin{array}{c}60.9 \\
( \pm 7.4)\end{array}$ & 1 & $7.03 * *$ \\
\hline TSI (SD) & $\begin{array}{c}56.8 \\
( \pm 3.2)\end{array}$ & $\begin{array}{c}46.3 \\
( \pm 5.2)\end{array}$ & $\begin{array}{c}51.5 \\
( \pm 6.8)\end{array}$ & $\begin{array}{c}58.1 \\
( \pm 4.9)\end{array}$ & $\begin{array}{c}48.2 \\
( \pm 6.9)\end{array}$ & $\begin{array}{c}53.2 \\
( \pm 7.8)\end{array}$ & 1 & 3.94 * \\
\hline $\mathrm{K}_{\mathrm{d}}\left(\mathrm{m}^{-1}\right)$ & $\begin{array}{c}1.67 \\
( \pm 0.9)\end{array}$ & $\begin{array}{c}0.97 \\
( \pm 0.4)\end{array}$ & $\begin{array}{c}1.32 \\
( \pm 0.7)\end{array}$ & $\begin{array}{c}1.86 \\
( \pm 0.7)\end{array}$ & $\begin{array}{c}1.25 \\
( \pm 0.8)\end{array}$ & $\begin{array}{c}1.56 \\
( \pm 0.8)\end{array}$ & 1 & $4.46^{*}$ \\
\hline $\mathrm{SD}(\mathrm{m})$ & $\begin{array}{c}1.28 \\
( \pm 0.3)\end{array}$ & $\begin{array}{c}2.75 \\
( \pm 0.9)\end{array}$ & $\begin{array}{c}2.03 \\
( \pm 1.0)\end{array}$ & $\begin{array}{c}1.21 \\
( \pm 0.4)\end{array}$ & $\begin{array}{c}2.51 \\
( \pm 1.1)\end{array}$ & $\begin{array}{c}1.86 \\
( \pm 1.0)\end{array}$ & 1 & 1.76 \\
\hline $\begin{array}{c}\text { Water temperature } \\
\left({ }^{\circ} \mathrm{C}\right)\end{array}$ & $\begin{array}{l}22.16 \\
( \pm 2.9)\end{array}$ & $\begin{array}{l}21.74 \\
( \pm 2.7)\end{array}$ & $\begin{array}{l}21.95 \\
( \pm 2.8)\end{array}$ & $\begin{array}{c}21.5 \\
( \pm 2.6)\end{array}$ & $\begin{array}{c}21.0 \\
( \pm 2.5)\end{array}$ & $\begin{array}{c}21.2 \\
( \pm 2.6)\end{array}$ & 1 & 2.71 \\
\hline $\mathrm{EC}\left(\mu \mathrm{S} \mathrm{cm}{ }^{-1}\right)$ & $\begin{array}{c}266.1 \\
( \pm 68.4)\end{array}$ & $\begin{array}{c}186.8 \\
( \pm 59.6)\end{array}$ & $\begin{array}{c}226.1 \\
( \pm 75.2)\end{array}$ & $\begin{array}{c}271.9 \\
( \pm 81.2)\end{array}$ & $\begin{array}{c}195.8 \\
( \pm 64.9)\end{array}$ & $\begin{array}{c}233.9 \\
( \pm 82.4)\end{array}$ & 1 & 0.46 \\
\hline $\mathrm{pH}$ & $\begin{array}{c}7.75 \\
( \pm 0.3)\end{array}$ & $\begin{array}{c}8.01 \\
( \pm 0.3)\end{array}$ & $\begin{array}{c}7.89 \\
( \pm 0.3)\end{array}$ & $\begin{array}{c}7.88 \\
( \pm 0.3)\end{array}$ & $\begin{array}{c}7.96 \\
( \pm 0.3)\end{array}$ & $\begin{array}{c}7.93 \\
( \pm 0.3)\end{array}$ & 1 & 0.03 \\
\hline $\mathrm{TN}\left(\mathrm{mg} \mathrm{L}^{-1}\right)$ & $\begin{array}{c}2.09 \\
( \pm 0.9)\end{array}$ & $\begin{array}{c}1.94 \\
( \pm 0.8)\end{array}$ & $\begin{array}{c}2.02 \\
( \pm 0.9)\end{array}$ & $\begin{array}{c}4.12 \\
( \pm 1.3)\end{array}$ & $\begin{array}{c}3.49 \\
( \pm 1.5)\end{array}$ & $\begin{array}{c}3.80 \\
( \pm 1.4)\end{array}$ & 1 & $96.88^{* * *}$ \\
\hline $\mathrm{TP}\left(\mathrm{mg} \mathrm{L}^{-1}\right)$ & $\begin{array}{c}0.16 \\
( \pm 0.1)\end{array}$ & $\begin{array}{c}0.15 \\
( \pm 0.2)\end{array}$ & $\begin{array}{c}0.16 \\
( \pm 0.2)\end{array}$ & $\begin{array}{c}0.05 \\
( \pm 0.0)\end{array}$ & $\begin{array}{c}0.04 \\
( \pm 0.0)\end{array}$ & $\begin{array}{c}0.04 \\
( \pm 0.0)\end{array}$ & 1 & $30.66^{* * *}$ \\
\hline P-PO4 $\left(\mathrm{mg} \mathrm{L}^{-1}\right)$ & $\begin{array}{c}0.03 \\
( \pm 0.0)\end{array}$ & $\begin{array}{c}0.02 \\
( \pm 0.0)\end{array}$ & $\begin{array}{c}0.03 \\
( \pm 0.0)\end{array}$ & $\begin{array}{c}0.01 \\
( \pm 0.0)\end{array}$ & $\begin{array}{c}0.01 \\
( \pm 0.0)\end{array}$ & $\begin{array}{c}0.01 \\
( \pm 0.0)\end{array}$ & 1 & $23.25^{* * *}$ \\
\hline
\end{tabular}


Table 2. Cont.

\begin{tabular}{|c|c|c|c|c|c|c|c|c|}
\hline \multirow{3}{*}{ Parameter } & \multirow{2}{*}{\multicolumn{3}{|c|}{$\begin{array}{c}\text { CW } \\
\text { Group of Lakes }\end{array}$}} & \multicolumn{3}{|c|}{ MW } & \multirow{3}{*}{$d f$} & \multirow{3}{*}{ F-test } \\
\hline & & & & & coup of $L$ & & & \\
\hline & A & B & $\begin{array}{c}\text { All } \\
\text { Lakes }\end{array}$ & A & B & $\begin{array}{c}\text { All } \\
\text { Lakes }\end{array}$ & & \\
\hline $\mathrm{DIN}\left(\mathrm{mg} \mathrm{L}^{-1}\right)$ & $\begin{array}{c}0.53 \\
( \pm 0.4)\end{array}$ & $\begin{array}{c}0.61 \\
( \pm 0.5)\end{array}$ & $\begin{array}{c}0.58 \\
( \pm 0.5)\end{array}$ & $\begin{array}{c}2.54 \\
( \pm 1.2)\end{array}$ & $\begin{array}{c}2.09 \\
( \pm 1.1)\end{array}$ & $\begin{array}{c}2.18 \\
( \pm 1.1)\end{array}$ & 1 & $144.78^{* * *}$ \\
\hline DIN:TN & $\begin{array}{c}0.28 \\
( \pm 0.2)\end{array}$ & $\begin{array}{c}0.32 \\
( \pm 0.2)\end{array}$ & $\begin{array}{c}0.30 \\
( \pm 0.2)\end{array}$ & $\begin{array}{c}0.52 \\
( \pm 0.2)\end{array}$ & $\begin{array}{c}0.58 \\
( \pm 0.2)\end{array}$ & $\begin{array}{c}0.55 \\
( \pm 0.2)\end{array}$ & 1 & $64.19^{* * *}$ \\
\hline P-PO4:TP & $\begin{array}{c}0.24 \\
( \pm 0.2)\end{array}$ & $\begin{array}{c}0.29 \\
( \pm 0.2)\end{array}$ & $\begin{array}{c}0.27 \\
( \pm 0.2)\end{array}$ & $\begin{array}{c}0.28 \\
( \pm 0.2)\end{array}$ & $\begin{array}{c}0.37 \\
( \pm 0.2)\end{array}$ & $\begin{array}{c}0.33 \\
( \pm 0.2)\end{array}$ & 1 & 3.4 \\
\hline TN:TP & $\begin{array}{c}25.3 \\
( \pm 25.2)\end{array}$ & $\begin{array}{c}34.0 \\
( \pm 30.4)\end{array}$ & $\begin{array}{c}29.7 \\
( \pm 28.2)\end{array}$ & $\begin{array}{c}94.9 \\
( \pm 49.9)\end{array}$ & $\begin{array}{c}110.2 \\
( \pm 55.1)\end{array}$ & $\begin{array}{c}102.6 \\
( \pm 52.7)\end{array}$ & 1 & $129.17^{* * *}$ \\
\hline
\end{tabular}

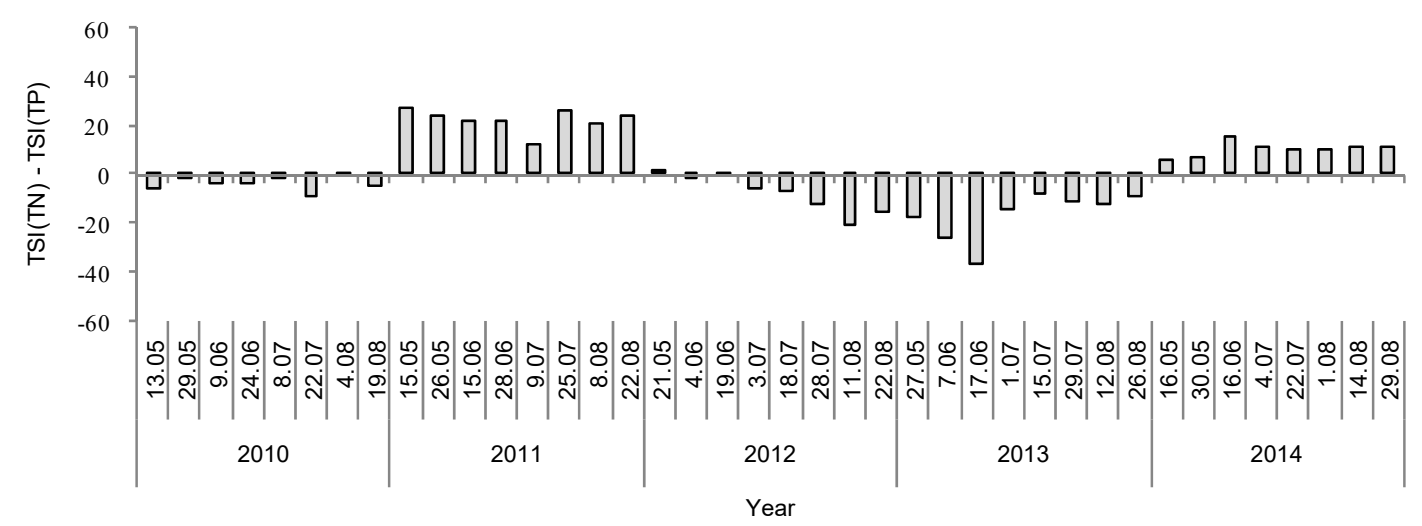

(a)

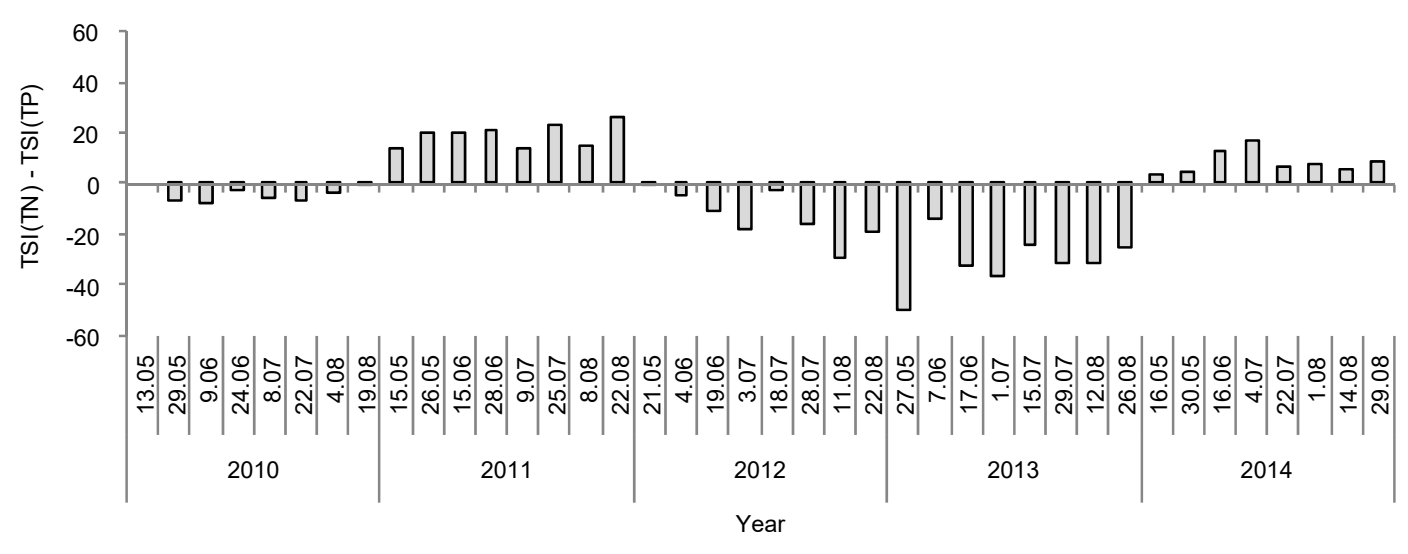

(b)

Figure 7. Cont. 


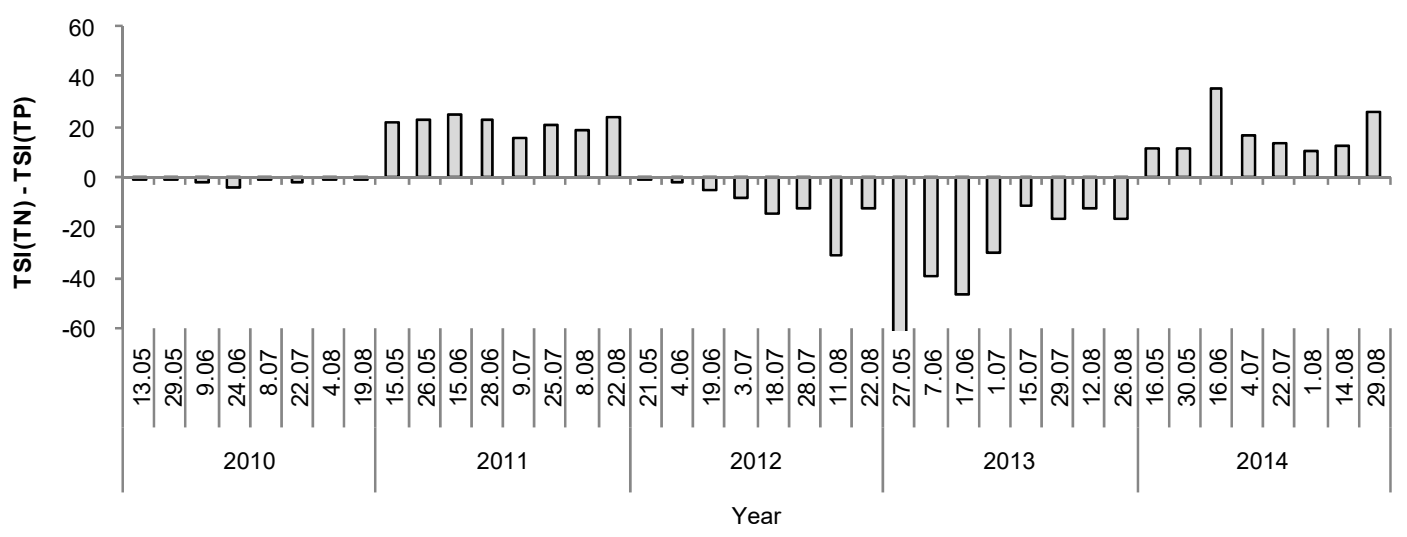

(c)

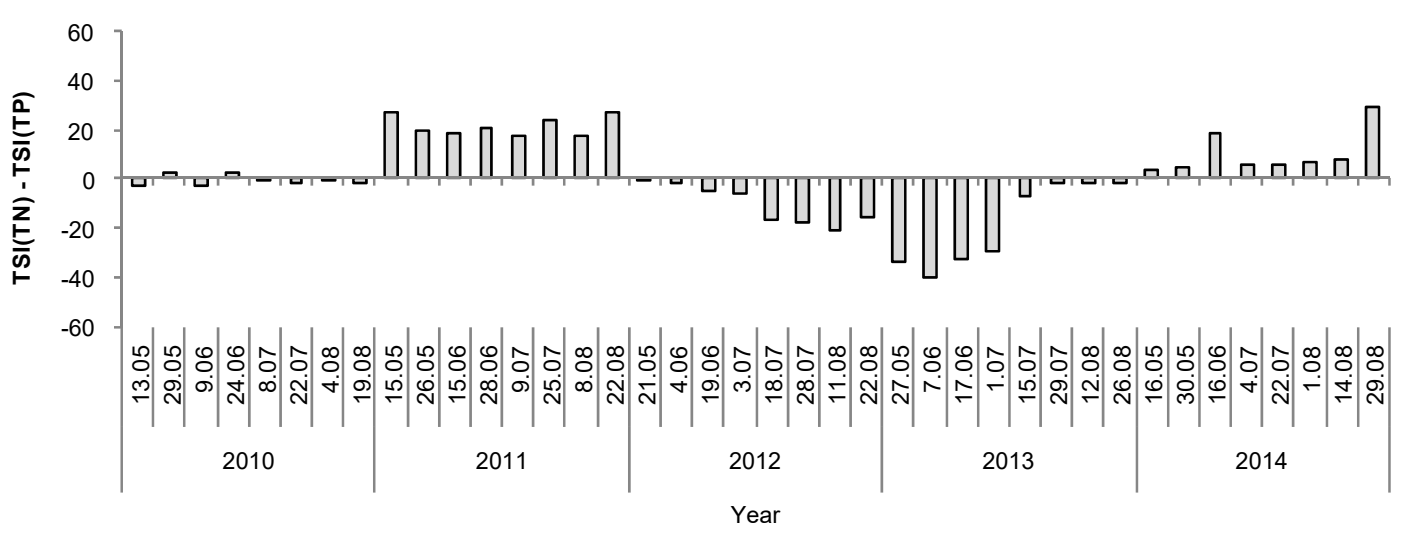

(d)

Figure 7. Temporal deviations in the values of trophic state indices (TSI(TN)-TSI(TP)) during the investigation period (2010-2014) in the studied lakes: (a) Głębokie; (b) Gumienek; (c) Czarne; (d) Maśluchowskie.

\section{Discussion}

In the eutrophic lakes studied here, we examined the complex factors determining the development of their phytoplankton communities, which were affected by changing weather conditions, as well as by changes within the lakes' aquatic environments. All of these transformations happen naturally, but today they are becoming much more intense and difficult to predict [39]. The study of microorganisms in winter under the ice and snow cover, or lack thereof, concerns the specificity of this season in the context of microorganism development, concurrently and also in the following seasons, that can strongly affect the aquatic food web [28-35,40]. Our study showed that the winter period had profound effects on the functioning of both the biotic components on a different level of organisation, as well as the abiotic elements of aquatic ecosystems during the vegetative growth season. Hence, the whole year should be treated as a continuum.

On the basis of the DCA results, the lakes were divided into two groups, A and B. It is interesting that these groups were separated according to the functional groups of phytoplankton present in them [56,57], whereas such a division did not occur according to classical taxonomic analyses. However, this "artificial division" in the DCA was based on assemblages of species reflecting the autecological and synecological characteristics of the phytoplankton community [56], which enabled us to differentiate between the phytoplankton communities of the studied lakes. Nevertheless, there were no further effects of these two separated groups (A and B) on the results analysed by two-way 
ANOVA. Hence, the main effect of the winter period (the CW and MW years) was the same, regardless of the group (A or B). In our study, most of the physical and chemical parameters considered (i.e., soluble and total nitrogen, TN:TP ratio, TSI(TN), and TSI(SD)) were significantly higher after a MW, whereas the values of soluble and total phosphorus content were significantly higher after a CW. The TN and TP content had opposite values, in the lakes' water during the vegetative growth season after a CW and a MW (Figure 7), as was expressed in the deviation model proposed by Havens [59], suggesting that nitrogen was a limiting factor for phytoplankton development after a CW, whereas phosphorus was a limiting factor after a MW. Low values of TP after mild winters and low values of TN after cold winters were also previously reported in an Estonian lake [37]. This finding is also supported by other studies, which pointed out the role of a lake's internal supply of nitrogen in the process of sediment resuspension, which might be very intensive after a MW as an effect of permanent water mixing [60]. Moreover, MW years were coupled with periods of high precipitation during the hydrological year, which could be another source of inorganic nitrogen from the atmosphere [15]. A similar effect was previously found with regard to the annual entrainment of suspended particulate matter and total phosphorus, which both increased linearly with the duration of the ice-free period [61]. However, this previous study was done in a large, shallow, polymictic lake that was well-exposed to the wind and had restricted macrophyte growth. In our study, high values of TP, and therefore nitrogen limitation, in the vegetative growth season were measured after a CW. This finding can be linked to the intensive runoff from the catchment basin caused by snow and ice melting after a cold winter [62]. Additionally, Blank et al. [63] found that high concentrations of TP in the spring after long-lasting ice cover, corresponding to periods with severe winters, were a possible effect of the internal release of phosphorus from deoxygenated lake bottom sediments. On the contrary, Sickman et al. [64] pointed out that there is high export of total nitrogen to lakes from the catchment soils during snowmelt runoff. Therefore, the amount of biogenic compounds in the water depends on both types of sources, internal and external, which can play more or less important roles depending on the occurrence of a specific type of winter (CW or MW).

In our study, both types of winter were coupled with differences in total precipitation, which was much higher during the hydrological years with a MW than in those with a CW. The same effect was found over a shorter period of time, restricted to only the vegetative growth season after either a MW or CW. This suggested that the occurrence of a MW or CW was linked with there being higher or lower total precipitation during the hydrological year, as well as with more or less precipitation during the vegetative growth season. Hence, the total precipitation, together with the type of winter, had profound effects on the abiotic and biotic parameters of the studied lakes in the context of long-term interactions. However, we also tested the effects of precipitation restricted to a shorter interval of 28 days (Figure 3), and we did not find any significant differences between the precipitation totals and the biological parameters expressed in the concentration of chlorophyll $a$ or total phytoplankton biomass. However, we found positive relationships between increasing air temperature and both the chlorophyll $a$ concentration and total phytoplankton biomass over a short interval of 14 days (Figure 3). This could suggest that the phytoplankton community is more susceptible to temperature increase than to precipitation events over short time intervals. In our study, only the biomasses of Cyanobacteria and Chlorophyta were positively correlated with increases in temperature $\left(\mathrm{T}_{14}\right.$ days $)$, with Spearman's correlation coefficients of 0.35 and 0.32 , respectively $(\mathrm{p}<0.001, \mathrm{n}=159)$. This supports the conclusion that warmer climates boost the percentage of the total phytoplankton biomass composed of Cyanobacteria, which is closely related to the effects of temperature increases [20]. On the other hand, previous experimental studies of selected species of Cyanobacteria and Chlorophyta showed that both phytoplankton groups can have similar optimum growth characteristics, with high growth rates at higher temperatures [42]. However, Rasconi et al. [65], on the basis of mesocosm experiments, suggested that the effect of temperature on the phytoplankton community should be considered on a long-term and multi-seasonal scale. Therefore, it is also well-known that cyanobacterial dominance 
is closely linked to eutrophication and global warming [5], which affect freshwater ecosystems on long timescales.

The characteristics of the phytoplankton community in the vegetative growth season were correlated with the type of winter, and as we mentioned above also with the precipitation totals, which were significantly higher after a MW than a CW. In our study, we showed that the values of chlorophyll $a$ concentrations and the phytoplankton biomass were significantly higher after a MW than after a CW (Table 2). As a consequence, the values of Carlson's indices associated with the phytoplankton community, such as TSI(CHL) and TSI(SD), as well as parameters describing the light climate in the water column, such as the values of the attenuation coefficient $\left(\mathrm{K}_{\mathrm{d}}\right)$ or Secchi disk visibility (SD), were also higher after a MW. Hence, we found significant correlations between the values of $K_{d}$ or $\mathrm{SD}$ and the phytoplankton biomass or chlorophyll $a$ concentration that indicated a strong effect on the phytoplankton community of the light conditions in the water column, and negligible effects of suspended particulate matter on the process of light absorption.

In terms of the phytoplankton community, we found that the biomass of only two groups, Cyanobacteria and Cryptophyceae, significantly increased after a MW. The effect of winter type was non-significant for the other phytoplankton groups examined. Taking into consideration the functional classification of phytoplankton used [56,57], we determined that the most important cyanobacterial species belonged to codons S1 and H1. Interestingly, the species from codon S1 dominated in Lakes Głebokie and Gumienek, whereas those from codon H1 dominated in Lakes Czarne and Maśluchowskie. Both functional groups are "typical" constituents of the phytoplankton communities of shallow, eutrophic lakes. However, the codon $\mathrm{H} 1$ is composed of $\mathrm{N}_{2}$-fixing cyanobacteria, and is thus favoured in lakes with nitrogen depletion ("less eutrophic"), whereas the codon S1 is composed of species with gas vesicles, which are resistant to the water mixing and changes in light intensity that are common in hypertrophic lakes in temperate regions (especially those exposed to wind mixing) with a high nutrient content $[16,56,57]$. Cyanobacterial biomass was significantly higher after a MW, and this change was coupled with elevated concentrations of soluble and total nitrogen. This is consistent with the previous results obtained by Havens et al. [66], as well as with the observation of Jankowiak et al. [67] from a field experiment, in which the cyanobacterial abundance significantly increased in response to elevated concentrations of nitrogen, or combined high nitrogen and phosphorus concentrations, and temperature treatments that concurrently suppressed the development of green and brown algae. These characteristics clearly reflect differences between the studied groups of lakes (groups A and B), that were also seen in the values of $K_{d}$ and SD describing the light climate in their water columns (Table 2). Such adaptations make cyanobacteria highly plastic to environmental changes and can help them to outcompete other phytoplankton groups in an unpredictable world [39]. Cryptophytes (codon $\mathrm{Y}$ ) were present in both groups of lakes (A and B), but independently of the effect of winter period, their biomass was always much higher in group A than in group B. Cryptophytes are tolerant to low light intensity, have the ability to change their position in the water column, and are able to ingest organic particles, which makes them largely independent of ambient nutrient concentrations [68]. All of these features allow them to compete in aquatic ecosystems with other phytoplankton species, including cyanobacteria. In the studied lakes, one other group, Chlorophyta, maintained high values of biomass, but the changes in its biomass between the CW and MW years were statistically non-significant. The species belonging to Chlorophyta were generally represented by the codons $\mathrm{F}$, J, and $\mathrm{P}$, which are typical species of shallow, meso-eutrophic or eutrophic lakes with well-mixed waters [56,57]. Chlorophytes from codons $\mathrm{F}, \mathrm{J}$, and $\mathrm{P}$, as well as cyanobacteria from codons $\mathrm{H} 1$ and $\mathrm{S} 1$, belong generally to the assemblage of large-sized species that can develop well in eutrophic ecosystems, and due to their size they are able to avoid heavy grazing by zooplankton [56]. Moreover, Lürling et al. [42] focused on the competitive advantages of cyanobacteria that enable them to migrate vertically and prevent sedimentation in warmer waters, as well as their resistance to grazing, especially when warming reduces zooplankton body size. These advantages might be a reason that cyanobacteria can outcompete chlorophytes, despite them having similar growth rates in warmer (optimal) conditions, especially in 
the face of the likely intensification of cyanobacterial blooms as a result of global warming [42]. On the other hand, cyanobacterial blooms can influence lake nutrient cycling and constitute an internal source of nitrogen and phosphorus in the water column, thereby increasing nutrient availability to other phytoplankton and microbes [69]. This seems to be very important in the development of chlorophytes, which can also undergo optimum growth at higher temperatures.

In this study, we also tested the effect of winter type on phytoplankton biodiversity. According to the results, the species richness, values of the Shannon-Wiener diversity index, and evenness (Pielou's index) of the communities were lower in the vegetative growth seasons after a MW than in those after a $\mathrm{CW}$. This suggests that the occurrence of a mild winter coupled with higher amounts of precipitation in the vegetative growth season negatively affects phytoplankton biodiversity. Hence, climate warming coupled with frequent mild winters could facilitate the mass development of phytoplankton blooms, although in the biomass produced only a few species (sometimes one or two) would be dominant. Consequently, climate warming can indirectly affect the biodiversity of phytoplankton communities in lakes in the temperate zone.

\section{Conclusions}

1. The changes in weather conditions, defined as fluctuations in air temperature and total precipitation, significantly affected the functioning of the aquatic ecosystem in the studied lakes in the temperate zone.

2. The occurrence of a cold or mild winter affected both the abiotic and biotic parameters of the studied lakes during the vegetative growth season.

3. The content of soluble and total nitrogen, concentration of chlorophyll $a$, total phytoplankton biomass, and biomasses of Cyanobacteria and Cryptophyceae were significantly higher in the vegetative growth seasons following a mild winter, whereas the content of soluble and total phosphorus and phytoplankton biodiversity were significantly lower in these years.

4. All of the features described in this study showed how sensitive lake ecosystems are to climatic fluctuations. The functioning of the lake ecosystems during the vegetative growth season was not only affected by climatic variability during the season itself, but also as a consequence of changes that took place earlier. Hence, climatic effects on lake ecosystems should always be considered over an extended period of time.

5. Climate warming coupled with frequent mild winters could promote the mass development of phytoplankton blooms, which could indirectly affect the biodiversity of phytoplankton communities in lakes in the temperate zone.

Author Contributions: Conceptualization, T.L. and W.E.; Methodology, T.L. and W.E.; Formal analysis, T.L. and W.E.; Investigation, T.L., W.E., and M.P.; Writing-original draft preparation, T.L.; Writing-review and editing, T.L. and M.P.

Funding: This research received no external funding.

Conflicts of Interest: The authors declare no conflict of interest.

\section{References}

1. George, D.G. The Impact of Climate Change on European Lakes; Springer: Dordrecht, The Netherlands, 2010.

2. Crutzen, P.J. Geology of mankind: The Anthropocene. Nature 2002, 415, 23. [CrossRef] [PubMed]

3. Steffen, W.; Persson, Å.; Deutch, L.; Zalasiewicz, J.; Williams, M.; Richardson, K.; Crumley, C.; Crutzen, P.; Folke, C.; Gordon, L.; et al. The Anthropocene: From Global Change to Planetary Stewardship. Ambio 2011, 40, 739-761. [CrossRef] [PubMed]

4. Beniston, M.; Stephenson, D.B.; Christensen, O.B.; Ferro, C.A.T.; Frei, C.; Goyette, S.; Halsnaes, K.; Holt, T.; Jylhä, K.; Koffi, B.; et al. Future Extreme Events in European Climate: An Exploration of Regional Climate Model Projections. Clim. Chang. 2007, 81, 71-95. [CrossRef]

5. Paerl, H.W.; Huisman, J. Blooms like it hot. Science 2008, 320, 57-58. [CrossRef] [PubMed] 
6. Dokulil, M.T. Predicting summer surface water temperatures for large Austrian lakes in 2050 under climate change scenarios. Hydrobiologia 2014, 731, 19-29. [CrossRef]

7. O’Reilly, C.M.; Sharma, S.; Gray, D.K.; Hampton, S.E.; Read, J.S.; Rowley, R.J.; Schneider, P.; Lenters, J.D.; McIntyre, P.B.; Kraemer, B.M.; et al. Rapid and highly variable warming of lake surface waters around the globe. Geophys. Res. Lett. 2015, 42, 773-781. [CrossRef]

8. Weyhenmeyer, G.A.; Meilei, M.; Livingstone, D.M. Nonlinear temperature response of lake ice breakup. Geophys. Res. Lett. 2004, 31, L07203. [CrossRef]

9. Marszelewski, W.; Skowron, R. Ice cover as an indicator of winter air temperature changes: Case study of the Polish Lowland lakes. Hydrol. Sci. J. 2006, 51, 336-349. [CrossRef]

10. Livingstone, D.M.; Adrian, R.; Blenckner, T.; George, G.; Weyhenmeyer, G.A. Lake ice phenology. In The Impact of Climate Change on European Lakes; George, D.G., Ed.; Aquatic Ecology Series 4; Springer Science+Business Media B.V.: London, UK; New York, NY, USA, 2010; pp. 51-61. [CrossRef]

11. Leppäranta, M. Modelling the formation and decay of lake ice. In The Impact of Climate Change on European Lakes; George, D.G., Ed.; Aquatic Ecology Series 4; Springer Science+Business Media B.V.: London, UK; New York, NY, USA, 2010; pp. 63-83. [CrossRef]

12. Moss, B.; Kosten, S.; Meerhoff, M.; Battarbee, R.W.; Jeppesen, E.; Mazzeo, N.; Havens, K.; Lacerot, G.; Liu, Z.; De Meester, L.; et al. Allied attack: Climate change and eutrophication. Inland Waters 2011, 1, 101-105. [CrossRef]

13. Paerl, H.W.; Scott, J.T. Throwing fuel on the fire: Synergistic effects of excessive nitrogen inputs and global warming on harmful algal blooms. Environ. Sci. Technol. 2010, 44, 7756-7758. [CrossRef] [PubMed]

14. Paerl, H.W.; Gardner, W.S.; Havens, K.E.; Joyner, A.R.; McCarthy, M.J.; Newell, S.E.; Qin, B.; Scott, J.T. Mitigating cyanobacterial harmful algal blooms in aquatic ecosystems impacted by climate change and anthropogenic nutrients. Harmful Algae 2016, 54, 213-222. [CrossRef] [PubMed]

15. Hessen, D.O.; Andersen, T.; Larsen, S.; Skjelkvåle, B.L.; de Wit, H.E. Nitrogen deposition, catchment productivity, and climate as determinants of lake stoichiometry. Limnol. Oceanogr. 2009, 54, 2520-2528. [CrossRef]

16. Dokulil, M.T.; Teubner, K. Cyanobacterial dominance in lakes. Hydrobiologia 2000, 438, 1-12. [CrossRef]

17. Wetzel, R. Limnology: Lake and River Ecosystems, 3rd ed.; Academic Press: San Diego/San Francisco, CA, USA; New York, NY, USA; Boston, MA, USA; London, UK; Sydney, Australia; Tokyo, Japan, 2001.

18. Ribeiro, K.F.; Duarte, L.; Crossetti, L.O. Everything is not everywhere: A tale on the biogeography of cyanobacteria. Hydrobiologia 2018, 820, 23-48. [CrossRef]

19. Johnk, K.D.; Huisman, J.; Sharples, J.P.; Sommeijer, B.; Visser, P.M.; Stroom, J.M. Summer heatwaves promote blooms of harmful cyanobacteria. Glob. Chang. Biol. 2008, 14, 495-512. [CrossRef]

20. Kosten, S.; Huszar, V.L.M.; Bécares, E.; Costa, L.S.; Van Donk, E.; Hansson, L.-A.; Jeppesen, E.; Kruk, C.; Lacerot, G.; Mazzeo, N.; et al. Warmer climates boost cyanobacterial dominance in shallow lakes. Glob. Chang. Biol. 2012, 18, 118-126. [CrossRef]

21. Elliott, J.A. Is the future blue-green? A review of the current model predictions of how climate change could affect pelagic freshwater cyanobacteria. Water Res. 2012, 46, 1364-1371. [CrossRef]

22. Reynolds, C.S.; Oliver, R.L.; Walsby, A.E. Cyanobacterial dominance: The role of buoyancy regulation in dynamic lake environments. N. Z. J. Mar. Freshw. Res. 1987, 21, 379-390. [CrossRef]

23. Carey, C.C.; Ibelings, B.W.; Hoffmann, E.P.; Hamilton, D.P.; Brookes, J.D. Eco-physiological adaptations that favour freshwater cyanobacteria in a changing climate. Water Res. 2012, 46, 1394-1407. [CrossRef]

24. Codd, G.A.; Morrison, L.F.; Metcalf, J.S. Cyanobacterial toxins: Risk management for health protection. Toxicol. Appl. Pharm. 2005, 203, 264-272. [CrossRef]

25. Nõges, P.; Adrian, R.; Anneville, O.; Arvola, L.; Blenckner, T.; George, G.; Jankowski, T.; Järvinen, M.; Maberly, S.; Padisák, J.; et al. The impact of variations in the climate on seasonal dynamics of phytoplankton. In The Impact of Climate Change on European Lakes; George, D.G., Ed.; Aquatic Ecology Series 4; Springer Science+Business Media B.V.: London, UK; New York, NY, USA, 2010; pp. 253-274. [CrossRef]

26. Lenard, T. Winter bloom of some motile phytoplankton under ice cover in a mesotrophic lake: Vertical distribution and environmental factors. Oceanol. Hydrobiol. Stud. 2015, 44, 164-171. [CrossRef]

27. Block, B.D.; Denfeld, B.A.; Stockwell, J.D.; Flaim, G.; Grossart, H.-P.F.; Knoll, L.B.; Maier, D.B.; North, R.L.; Rautio, M.; Rusak, J.A.; et al. The unique methodological challenges of winter limnology. Limnol. Oceanogr. Methods 2019, 17, 42-57. [CrossRef] 
28. Lenard, T.; Wojciechowska, W. Phytoplankton diversity and biomass during winter with and without ice cover in the context of climate change. Pol. J. Ecol. 2013, 61, 739-748.

29. Hayden, B.; Harrod, C.; Kahilainen, K.K. The effects of winter ice cover on the trophic ecology of whitefish (Coregonus lavaretus L.) in subarctic lakes. Ecol. Freshw. Fish 2013, 22, 192-201. [CrossRef]

30. Wojciechowska, W.; Lenard, T. Effect of extremely severe winters on under-ice phytoplankton development in a mesotrophic lake (Eastern Poland). Oceanol. Hydrobiol. Stud. 2014, 43, 147-153. [CrossRef]

31. Hampton, S.E.; Moore, M.V.; Ozersky, T.; Stanley, E.H.; Polashenski, C.M.; Galloway, A.W.E. Heating up a cold subject: Prospects for under-ice plankton research in lakes. J. Plankton Res. 2015, 37, 277-284. [CrossRef]

32. Kalinowska, K.; Grabowska, M. Autotrophic and heterotrophic plankton under ice in a eutrophic temperate lake. Hydrobiologia 2016, 777, 111-118. [CrossRef]

33. Özkundakci, D.; Gsell, A.S.; Hintze, T.; Täuscher, H.; Adrian, R. Winter severity determines functional trait composition of phytoplankton in seasonally ice-covered lakes. Glob. Chang. Biol. 2016, 22, 284-298. [CrossRef]

34. Grosbois, G.; Mariash, H.; Schneider, T.; Rautio, M. Under-ice availability of phytoplankton lipids is key to freshwater zooplankton winter survival. Sci. Rep. 2017, 7, 11543. [CrossRef]

35. Hampton, S.E.; Galloway, A.W.E.; Powers, S.M.; Ozersky, T.; Woo, K.H.; Batt, R.D.; Labou, S.G.; O’Reilly, C.M.; Sharma, S.; Lottig, N.R. Ecology under lake ice. Ecol. Lett. 2017, 20, 98-111. [CrossRef]

36. Glé, C.; Del Amo, Y.; Bec, B.; Sautour, B.; Froidefond, J.-M.; Gohin, F.; Maurer, D.; Plus, M.; Laborde, P.; Chardy, P. Typology of environmental conditions at the onset of winter phytoplankton blooms in a shallow macrotidal coastal ecosystem, Arcachon bay (France). J. Plankton Res. 2007, 29, 999-1014. [CrossRef]

37. Laugaste, R.; Haberman, J.; Blank, K. Cool winters versus mild winters: Effects on spring plankton in Lake Peipsi. Est. J. Ecol. 2010, 59, 163-183. [CrossRef]

38. Weyhenmeyer, G.A.; Westöö, A.-K.; Willén, E. Increasingly ice-free winters and their effects on water quality in Sweden's largest lakes. Hydrobiologia 2008, 599, 111-118. [CrossRef]

39. Lürling, M.; De Senerpont Domis, L.N. Predictability of plankton communities in an unpredictable world. Freshw. Biol. 2013, 58, 455-462. [CrossRef]

40. Pełechata, A.; Pełechaty, M.; Pukacz, A. Winter temperature and shifts in phytoplankton assemblages in asmall Chara-lake. Aquat. Bot. 2015, 124, 10-18. [CrossRef]

41. Lenard, T.; Ejankowski, W. Natural water brownification as a shift in the phytoplankton community in a deep hard water lake. Hydrobiologia 2017, 787, 153-166. [CrossRef]

42. Lürling, M.; Eshetu, F.; Faassen, E.J.; Kosten, S.; Huszar, V.L.M. Comparison of cyanobacterial and green algal growth rates at different temperatures. Freshw. Biol. 2013, 58, 552-559. [CrossRef]

43. Kondracki, J. Geografia regionalna Polski; Wyd. Naukowe PWN: Warszawa, Poland, 2002.

44. Ejankowski, W.; Lenard, T. Trophic state of a shallow lake with reduced inflow of surface water. Arch. Environ. Prot. 2014, 40, 3-11. [CrossRef]

45. Bajkiewicz-Grabowska, E. Assessment of the ecological state of lakes as proposed by the Polish Limnological Society. Limnol. Rev. 2010, 10, 105-116. [CrossRef]

46. Wilgat, T.; Michalczyk, Z.; Turczyński, M.; Wojciechowski, K. The Łęczna-Włodawa Lakes. Stud. Ośr Dok Fizjogr PAN 1991, 19, 23-140.

47. Nush, E.A. Comparison of different methods for chlorophyll and pheopigment determination. Arch. Hydrobiol. 1980, 14, 14-36.

48. Hermanowicz, W.; Dojlido, J.; Dożańska, W.; Koziorowski, B.; Zerbe, J. Fizyczno-Chemiczne Badanie Wody I Ścieków; Wyd. Arkady: Warszawa, Poland, 1999.

49. Kirk, J.T.O. Light and Photosynthesis in Aquatic Ecosystems; Cambridge University Press: Cambridge, UK, 1994.

50. Carlson, R.E. A trophic state index for lakes. Limnol. Oceanogr. 1977, 22, 361-369. [CrossRef]

51. Kratzer, C.R.; Brezonik, P.L. A Carlson-type trophic state index for nitrogen in Florida lakes. Water Resour. Bull. 1981, 17, 713-715. [CrossRef]

52. Utermöhl, H. Zur Vervolkommnung der quantitativen Planktonmethodik. Mitt. Int. Ver. Für Theor. Angew. Limnol. 1958, 9, 1-38.

53. Hillebrand, H.; Dürselen, C.D.; Kirschtel, D.; Pollingher, U.; Zohary, T. Biovolume calculation for pelagic and benthic microalgae. J. Phycol. 1999, 35, 403-424. [CrossRef]

54. Shannon, C.E.; Wiener, W. The Mathematical Theory of Communication; University of Illinois Press: Urbana, IL, USA, 1963. 
55. Pielou, E.C. Ecological Diversity; John Wiley \& Sons: New York, NY, USA, 1975.

56. Reynolds, C. The Ecology of Phytoplankton. Ecology, Biodiversity and Conservation; Cambridge University Press: Cambridge, UK, 2006.

57. Padisák, J.; Crossetti, L.O.; Naselli-Flores, L. Use and misuse in the application of the phytoplankton functional classification: A critical review with updates. Hydrobiologia 2009, 621, 1-19. [CrossRef]

58. Sokal, R.R.; Rohlf, F.J. Biometry, 3rd ed.; W.H. Freeman and Company: New York, NY, USA, 1995.

59. Havens, K.E. Secondary nitrogen limitation in a subtropical lake impacted by non-point source agricultural pollution. Environ. Pollut. 1995, 89, 241-246. [CrossRef]

60. Nõges, T.; Nõges, P. The effect of extreme water level decrease on hydrochemistry and phytoplankton in a shallow eutrophic lake. Hydrobiologia 1999, 408/409, 277-283. [CrossRef]

61. Kleeberg, A.; Freidank, A.; Jöhnk, K. Effects of ice cover on sediment resuspension and phosphorus entrainment in shallow lakes: Combining in situ experiments and wind-wave modeling. Limnol. Oceanogr. 2013, 58, 1819-1833. [CrossRef]

62. Klimaszyk, P.; Rzymski, P. Surface runoff as a factor determining trophic state of midforest lake. Pol. J. Environ. Stud. 2011, 20, 1203-1210.

63. Blank, K.; Haberman, J.; Haldna, M.; Laugaste, R. Effect of winter conditions on spring nutrient concentrations and plankton in a large shallow Lake Peipsi (Estonia/Russia). Aquat. Ecol. 2009, 43, 745-753. [CrossRef]

64. Sickman, J.O.; Leydecker, A.; Chang, C.C.Y.; Kendall, C.; Melack, J.M.; Lucero, D.M.; Schimel, J. Mechanisms underlying export of $\mathrm{N}$ from high-elevation catchments during seasonal transitions. Biogeochemistry 2003, 64, 1-24. [CrossRef]

65. Rasconi, S.; Winter, K.; Kainz, M.J. Temperature increase and fluctuation induce phytoplankton biodiversity loss-Evidence from a multi-seasonal mesocosm experiment. Ecol. Evol. 2017, 7, 2936-2946. [CrossRef] [PubMed]

66. Havens, K.E.; Paerl, H.; Phlips, E.J.; Zhu, M.; Beaver, J.R.; Srifa, A. Extreme weather events and climate variability provide a lens into how shallow lakes may respond to climate change. Water 2016, 8, 229. [CrossRef]

67. Jankowiak, J.; Hattenrath-Lehmann, T.; Kramer, B.J.; Ladds, M.; Gobler, C.J. Deciphering the effects of nitrogen, phosphorus, and temperature on cyanobacterial bloom intensification, diversity, and toxicity in western Lake Erie. Limnol. Oceanogr. 2019, 1-24. [CrossRef]

68. Lepistö, L.; Saura, M. Effects of forest fertilization on phytoplankton in boreal brown-water lake. Boreal Environ. Res. 1998, 3, 33-43.

69. Cottingham, K.L.; Ewing, H.A.; Greer, M.L.; Carey, C.C.; Weathers, K.C. Cyanobacteria as biological drivers of lake nitrogen and phosphorus cycling. Ecosphere 2015, 6, 1-19. [CrossRef] 